\title{
Artist versus Anatomist, Models against Dissection: Paul Zeiller of Munich and the Revolution of 1848
}

\author{
NICK HOPWOOD*
}

The uses of anatomical models in medical teaching changed dramatically during the nineteenth century. The most celebrated Enlightenment ceroplastics, the royal collections directed by the natural philosopher Felice Fontana in Florence and copied for the militarymedical academy in Vienna, united science and art in three-dimensional encyclopaedias of the body. According to Fontana, one could learn more from the models in six months than from dissecting scarce human cadavers in six years. But he gave up wax for wood, and by the early nineteenth century anatomists routinely disparaged his collections as white elephants. Beauty and truth no longer went hand in hand. As anatomy broke up into specialized research programmes, works intended also for the public were criticized as aristocratic luxuries and vulgar entertainments. Above all, medicine's rising authority was grounded in direct engagement with bodies, dead and alive. So when professors no longer had to rely on criminal corpses, but gained access to those of the poor, models were marginalized before they could seriously challenge dissection. They kept important roles in obstetrics, and gained new ones in specialties where objects were especially complex, rare, transient, hard-to-preserve and/or tiny, notably in pathology, dermatology and embryology. But wax, plaster, wood and papier mâché were uncomfortably as well as strategically placed between prepared body parts, with their stronger claim to authenticity, and drawings, which were more established and easily reproduced. By the end of the century models of normal adult anatomy, now mostly commercially made, were more widely used in medical education than ever before, but for special purposes only. ${ }^{1}$

\section{(C) Nick Hopwood 2007}

*Nick Hopwood, MSc, PhD, Department of History and Philosophy of Science, University of Cambridge, Free School Lane, Cambridge CB2 3RH, UK.

I thank the institutions credited as holding materials. In Munich, Florian Dering (Stadtmuseum), Reinhard Heydenreuter (Archiv der Bayerischen Akademie der Wissenschaften), Ursula Lochner (Archiv der Ludwigs-Maximilians-Universität), Anton

Löffelmeier (Stadtarchiv), Reinhard Putz

(Anatomisches Institut) and Joachim Wild

(Bayerisches Hauptstaatsarchiv) were especially generous with time and expertise. I am very grateful to Peter Dorsch for searching newspapers and Ulrike Lindner for putting us in touch, Elsbeth Schramm for allowing me to reproduce pictures from a family album, and Pierre Buisseret and Cédric Crémière for showing me models at the Muséum national d'Histoire naturelle.
The text was improved by comments from Tatjana Buklijas, Silvia De Renzi, Nick Jardine, Ayako Sakurai, Paul Ziche, three referees and audiences at talks in this department and at the 2005 meeting of the AAHM. Research was supported by the Wellcome Trust.

${ }^{1}$ Thomas N Haviland and Lawrence Charles Parish, 'A brief account of the use of wax models in the study of medicine', J. Hist. Med. Allied Sci., 1970, 25: 52-75, pp. 68-9; Urs Boschung, 'Medizinische Lehrmodelle. Geschichte, Techniken, Modelleure', Medita, 1980, 10 (Folge 4 zur Geschichte der Medizin und der medizinischen Technik): ii-xv; Heike Kleindienst, 'Ästhetisierte Anatomie aus Wachs. Ursprung - Genese - Integration', dr phil. diss., 2 vols, Universität Marburg, 1989; Michel Lemire, Artistes et mortels, Paris, Chabaud, 1990, pp. 323-65; Thomas Schnalke, Diseases in wax: the history of the medical moulage, Berlin, Quintessence, 1995, p. 49. In general 


\section{Nick Hopwood}

No simple effect of increased corpse supply, this shift was negotiated by those involved in anatomy teaching at the same time as dissection was hotly debated. Johann Wolfgang von Goethe's appeal for "plastic anatomy" vividly links the two discussions. The poet had dissected human cadavers and as a government minister been responsible for an anatomical institute, but, as reports of grave-robbing and murder spread from Britain, the old man rejected harsh new laws to requisition pauper corpses and advocated models as a humane surrogate for dissection. ${ }^{2}$ In Wilhelm Meister's Travels (1829) a mysterious sculptor leads the troubled Wilhelm away from a beautiful female cadaver to a workshop for models. The artist, based on Fontana, explains Romantically that "building up teaches more than tearing apart, joining together more than separating, animating what is dead more than killing over again what has already been killed". Wilhelm becomes a "plastic anatomist".3 But Goethe's proposal of an institute of plastic anatomy for Berlin was rejected a few weeks before he died in 1832 and histories of modelling report no further reception of his comments until the 1890s. ${ }^{4}$ This failure appears to confirm that models had lost any chance of substituting for dissection. Only recently have medical schools begun to take alternatives seriously. ${ }^{5}$

Yet that is not the whole story. Medical professors were the main patrons and customers, but they could not dictate models' production and uses. Many modellers-a diverse bunch of artists and doctors - did accept the medical control that increasingly limited artists' autonomy. Mid-century initiatives worked around the growing dominance of dissection by collaborating with discipline-builders to carve out more specialized niches, carefully negotiating the conditions under which models of normal adult anatomy would have a role, or concentrating on lay audiences. ${ }^{6}$ But Fontana had difficulty managing artists he

on models, see Soraya de Chadarevian and Nick Hopwood (eds), Models: the third dimension of science, Stanford University Press, 2004; and specifically on

Fontana, Renato G Mazzolini, 'Plastic anatomies and artificial dissections', in ibid., pp. 43-70.

${ }^{2}$ Ulrike Enke and Manfred Wenzel, " "Wißbegierde" contra "Menschlichkeit". Goethes ambivalentes Verhältnis zur Anatomie in seiner Dichtung und Biographie', Goethe-Jahrbuch, 1998, 115: 155-70; Irmgard Egger, "“Verbinden mehr als Trennen". Goethe und die plastische Anatomie', Germanisch-Romanische Monatsschrift, 2001, 51: 45-53. On corpse supply to nineteenth-century anatomy, see especially Ruth Richardson, Death, dissection and the destitute, Harmondsworth, Penguin, 1988; Michael Sappol, A traffic of dead bodies: anatomy and embodied social identity in nineteenthcentury America, Princeton University Press, 2002; Elizabeth T Hurren, 'A pauper dead-house: the expansion of the Cambridge anatomical teaching school under the late-Victorian Poor Law, 1870-1914', Med. Hist., 2004, 48: 69-94; and Helen MacDonald, Dissection and its histories, New Haven, Yale University Press, 2006. On the German lands, see Karin Stukenbrock, "Der zerstückte Cörper". Zur Sozialgeschichte der anatomischen Sektionen in der frühen Neuzeit (1650-1800), Stuttgart, Steiner, 2001;
Tatjana Buklijas, 'Dissection, discipline and urban transformation: anatomy at the University of Vienna, 1845-1914', PhD thesis, University of Cambridge, 2005, chs 2 and 7; and the other works cited in note 18 below.

${ }^{3}$ Johann Wolfgang Goethe, Wilhelm Meisters Wanderjahre, ed. Gerhard Neumann and Hans-Georg Dewitz, Frankfurt am Main, Deutscher Klassiker Verlag, 1989, pp. 599-612, on pp. 604, 609. This translation is modified from Goethe, Wilhelm Meister's Travels, transl. by Edward Bell, London, Bell and Sons, 1882 , pp. 301, 305; the others are my own.

${ }^{4} \mathrm{~J}$ Schwalbe, 'Zur Geschichte der "plastischen Anatomie",, Deutsche medizinische Wochenschrift, 1896, 22: 761-2; Schnalke, op. cit., note 1 above, pp. 58-62.

${ }^{5}$ Debate forum, Anat. Rec. (New Anat.), 2004, 281B: 2-14. For Goethe's relevance, see Charleen M Moore and C Mackenzie Brown, 'Gunther von Hagens and Body Worlds. Part 1: the anatomist as prosektor and proplastiker', ibid., 2004, 276B: 8-14.

${ }^{6}$ See the surveys cited in note 1 above and Audrey B Davis, 'Louis Thomas Jerôme Auzoux and the papier mâché anatomical model', in La ceroplastica nella scienza e nell'arte ..., 2 vols, Florence, Olschki, 1977, vol. 1, pp. 257-79; B W J Grob, The anatomical models of Dr. Louis Auzoux, Leiden, Museum Boerhaave, 


\section{Models, Dissection and the Revolution of 1848}

treated as hired hands, ${ }^{7}$ and professors in early nineteenth-century France had to push modellers used to aristocratic commissions to submit to the disciplines of professional science. ${ }^{8}$ The same move to learning by seeing and doing that created opportunities for makers of visual aids also fixed dissection in the medical curriculum. But though widely recognized by law, it remained controversial as a final punishment for poverty, and the relative merits of natural and artificial preparations continued to be discussed. ${ }^{9}$

This article aims to expand our understanding of the range of mid-nineteenth-century negotiations over models and dissection, and to recover their ferocity. It is about Paul Zeiller (1820-93), a previously little-researched modeller who uncompromisingly challenged anatomical authority. ${ }^{10} \mathrm{He}$ did not work in Paris or Vienna, the main centres of innovation, ${ }^{11}$ but in Munich, a bastion of Romanticism and reaction. Home to an active wax industry, the Bavarian capital of the arts and sciences in Catholic southern Germany provided the conditions in the mid-1840s for Zeiller to launch an extraordinary modelling career. Following some academically acclaimed work and the creation of a university position, during the 1848 revolution he confronted the professor of anatomy, demanding autonomy and drawing on Goethe to insist that his models should save proletarian corpses from dissection. Zeiller lost this argument, but kept his job until he resigned to found an anthropological museum. He and his wife Franziska Zeiller continued through the 1860s and 1870 s to campaign against "knife anatomy".

Since Zeiller was both employed by the state and extremely embattled, more voluminous documents were generated than usual for such secretive artisans, and enough survive to offer exceptionally rich evidence of what was at stake. ${ }^{12}$ His struggles throw other modellers' strategies into relief and show that models' roles in relation to dissection and natural preparations were more intensely contested, and later, than has been assumed. More generally, the case illustrates how negotiations over the media of anatomical representation have intersected with the larger politics of death, dissection and the destitute. By also shedding light on the agendas and relations of private museums, it further expands our picture of medical science in and after 1848 .

2004; Nick Hopwood, Embryos in wax: models from the Ziegler studio, with a reprint of 'Embryological wax models' by Friedrich Ziegler, Cambridge, Whipple Museum of the History of Science, and Bern, Institute of the History of Medicine, 2002; and Henri Reiling, 'The Blaschkas' glass animal models: origins of design', J. Glass Stud., 1998, 40: 105-26.

${ }^{7}$ Mazzolini, op. cit., note 1 above, pp. 52-3.

${ }^{8}$ Lemire, op. cit., note 1 above, pp. 159-60; Emma Spary, 'Forging nature at the Republican Muséum', in Lorraine Daston and Gianna Pomata (eds), The faces of nature in Enlightenment Europe, Berlin, Berliner Wissenschafts-Verlag, 2003, pp. 163-80, on pp. 172-3. On the related struggles of preparators and university artists, see Susanne Köstering, Natur zum Anschauen Das Naturkundemuseum des deutschen Kaiserreichs 1871-1914, Cologne, Böhlau, 2003, pp. 153-83; and Elke Schulze, Nulla dies sine linea. Universitärer Zeichenunterricht: eine problemgeschichtliche Studie, Stuttgart, Steiner, 2004, pp. 105-25.

\footnotetext{
${ }^{9}$ Lemire, op. cit., note 1 above, pp. 383-4.

${ }^{10}$ Two unreferenced paragraphs in Hannes König and Erich Ortenau, Panoptikum. Vom Zauberbild zum Gaukelspiel der Wachsfiguren, Munich, Isartal, 1962, p. 95 (plus photographs on pp. 92-4 and 104) are the basis for the descriptions in Heinrich Röhrich, 'Die Wachsbossierer, Hersteller anatomischer Lehrmodelle in München', in Ceroplastica, op. cit., note 6 above, vol. 1, pp. 433-41, on p. 437; and Charlotte Angeletti, Geformtes Wachs. Kerzen, Votive, Wachsfiguren, Munich, Callwey, 1980, p. 33. See also Max Ernst, 'Vom Wachszieher zum Kgl. Professor. Paul Zeiller (I)', in idem (ed.), Grünwalder Porträts, Grünwald, 1990, pp. 31-2. These accounts give no hint of the conflicts I focus on here.

${ }^{11}$ Lemire, op. cit., note 1 above; Schnalke, op. cit., note 1 above, pp. 75-110.

${ }^{12}$ But we have few models, many ministerial files were destroyed and the social history of Munich anatomy has hardly been studied.
} 




Figure 1: The neoclassical façade of the Munich anatomical institute by Leo von Klenze. On the north-east corner of the Theresienwiese, site of the Oktoberfest, the institute, which was greatly enlarged in 1855, was only a block away from the large General Hospital. From Ignaz Döllinger, Bericht von dem neuerbauten anatomischen Theater der Königlichen Akademie der Wissenschaften, Munich, 1826, plate 1. Niedersächsische Staats- und Universitätsbibliothek Göttingen.

\section{Anatomical Wax Preparator to Ludwig I of Bavaria}

Ludwig I sought from his coronation in 1825 to ensoul the rational mechanism of the modern Bavarian state, created during the Napoleonic era, with history and Christianity, especially Catholicism. In this climate speculative Romanticism, especially the now deeply religious nature philosophy of Friedrich von Schelling, president of the Bavarian Academy of Sciences, was in power long after it had gone out of fashion elsewhere. Art was assigned a special role in publicly cultivating tradition and rekindling the faith through which knowledge was to be reborn. Munich, already home to an Academy of Arts, gained grandiose classical buildings for museums, churches, monuments and the state's largest university, which Ludwig transferred from Landshut in 1826. To an exceptional degree, the city now fostered the union of science and art. ${ }^{13}$ What did it mean to make anatomical models here?

In 1823 the outstanding anatomist Ignaz Döllinger had moved from Würzburg to the Academy of Sciences in Munich. The institute built for him by Ludwig's favourite architect then served the university (Figure 1). Döllinger became professor of anatomy, while remaining "conservator", responsible to the academy for most of the collection. Indebted to Schelling, he was committed to empirical investigation as the means to

\footnotetext{
${ }^{13}$ Max Spindler, 'Die Regierungszeit Ludwigs I. (1825-1848)', in Handbuch der bayerischen Geschichte, 4 vols, idem (ed.), vol. 4: Das neue Bayern 1800-1970, Munich, Beck, 1974, part 1: Staat und Politik(1800-1970), pp. 87-223, especially pp. 121-2, 127; Harald Dickerhof, 'Aufbruch in München', in Laetitia Boehm and Johannes Spörl (eds), Ludwig-Maximilians-Universität. IngolstadtLandshut-München 1472-1972, Berlin, Duncker \&
}

Humblot, 1972, pp. 215-50; James J Sheehan, Museums in the German art world: from the end of the old regime to the rise of modernism, Oxford University Press, 2000, pp. 58-70; Frank Büttner, 'Ludwig I. Kunstförderung und Kunstpolitik', in Alois Schmid and Katharina Weigand (eds), Die Herrscher Bayerns. 25 historische Porträts von Tassilo III. bis Ludwig III., Munich, Beck, 2001, pp. 314-33. 


\section{Models, Dissection and the Revolution of 1848}

a dynamic understanding of living things. A leading practitioner of morphology, Goethe's science of organic form, Döllinger promoted comparative anatomy and especially embryology. The anatomist should seek, he argued, "to reveal the laws of formation which nature follows in the development of her most noble work ... so that a body shall emerge which may be worthy to serve an immortal spirit as temporal home". In Würzburg he had inspired the ground-breaking embryological work of Christian Pander and Karl Ernst von Baer. $^{14}$

Yet Döllinger fell ill in 1836, died in 1841 and was not replaced. There followed a period of decline, with cramped accommodation for the many subjects still taught in the faculty's only non-clinical institute, low scientific output and little connection to such innovative centres as Johannes Müller's Berlin. Nevertheless, for all the criticism of the medical faculty as mired in speculation and even mysticism, Döllinger's protégés were committed to empirical work. His prosector Eugen Schneider, a full professor since 1832, was appointed acting conservator and director, and Anton Förg the new prosector. But hopes for a revival rested on Döllinger's young favourite, the comparative anatomist and embryologist Michael Erdl, widely published, artistically talented, devout and well travelled, including to the Holy Land, but sickly. Schneider, a popular teacher with an extensive, mainly surgical, practice, authored a few short publications, largely in pathological anatomy, but concentrated on augmenting the collection of demonstration specimens, an important sign of an institute's worth. ${ }^{15}$

Specimen preparation and dissection classes depended on cadaver supply. In the early 1830 s the Munich anatomical institute received 350 corpses a year from the nearby General Hospital. The poor were buried in the usual way at the hospital's expense after post mortem and/or dissection. But since many bodies arrived in the summer and some went for surgical courses, only 180 on average were available for the winter dissection season; post mortems reduced many of these to just a few usable parts. The prison across the Isar river in the suburb of Au also supplied cadavers. But though the institute counted as well supplied-it supported ninety-eight dissectors in 1833-4 - students were often turned away for lack of material. $^{16}$

\footnotetext{
${ }^{14}$ Ignaz Döllinger, Bericht von dem neuerbauten anatomischen Theater der Königlichen Akademie der Wissenschaften, Munich, 1826, p. 7: "die BildungsGesetze zu enthüllen, welche die Natur bei der Entwicklung ihres edelsten Werkes befolgt ... damit ein Leib entstehe, der würdig sey, einem unsterblichen Geiste zum zeitlichen Wohnorte zu dienen." See further [Friedrich] Wassermann, 'Die anatomische Anstalt', in Karl Alexander von Müller (ed.), Die wissenschaftlichen Anstalten der Ludwig-MaximiliansUniversität zu München ..., Munich, Oldenbourg und Wolf \& Sohn, 1926, pp. 36-51; Timothy Lenoir, The strategy of life: teleology and mechanics in nineteenthcentury German biology, University of Chicago Press, 1989, pp. 65-71; and Robert J Richards, The romantic conception of life: science and philosophy in the age of Goethe, University of Chicago Press, 2002.
}

\footnotetext{
${ }^{15}$ Publications and biographies are listed in Achim Eberhardt, 'Personalbibliographien der Professoren und Dozenten der medizinischen Fakultät der Universität München von 1826-1848 ...', dr med. diss., Universität Erlangen-Nürnberg, 1971.

${ }^{16}$ Eugen Schneider, Beglückwünschung Seiner Hochwohlgeboren dem Herrn Dr. Ignatz Döllinger .... Nebst einem Bericht von dem Zustande und den Leistungen der k. anatomischen Anstalt zu München, Munich, 1834, pp. 24-5. On the patients, see Reinhard Spree, 'Sozialer Wandel im Krankenhaus während des 19. Jahrhunderts. Das Beispiel des Münchner Allgemeinen Krankenhauses', Medizinhist. J., 1998, 33: 245-91; on burial, Neueste Nachrichten aus dem Gebiete der Politik, 27 Aug. 1848, no. 141, 1542; and for the prison supply, Archiv der LudwigsMaximilians-Universität München (hereafter UAM),
} 


\section{Nick Hopwood}

In Britain and the United States around this time opposition to grave-robbing, "burking" and dissection erupted in riots, ${ }^{17}$ but we have less evidence of protest in the German lands. From the eighteenth century, regulations requisitioning corpses were expanded geographically and from executed criminals to include the more exposed members of various other marginal groups: suicides, unmarried mothers, the illegitimate, the unknown and the more or less unclaimed bodies of those dying in prisons, poorhouses, orphanages and especially hospitals, who would have to be buried at state expense. Pleas for exemption were common and passive resistance was widespread, but supply increased gradually with demand, seemingly without the gross British abuses that had so troubled Goethe. Anatomical institutes were widely viewed with horror and people complained about offences against public decency, but the regulations look to have been tolerated with little organized popular opposition until the mid-nineteenth century. The Catholic Church appears more relaxed about dissection, provided the remains were buried properly, but we lack clear evidence of a confessional divide; both Catholic and Protestant clerics are known to have collaborated, and class may have affected attitudes more. ${ }^{18}$ In Munich around 1848 it was generally accepted that anatomy and the lower classes were united only by mutual fear, and critics pointed out that precisely those most afraid were most likely to be cut up. But Schneider claimed that there had been no disturbances until the revolution. ${ }^{19}$

A few corpses went for "wax preparations". ${ }^{20}$ Like most other anatomists, who saw Fontana's experiment as having failed, Döllinger balanced praise for models with concern to prevent the view gaining ground that these could ever substitute for dissection. He was reluctant to buy, expressed an interest in close control over modellers' work and highlighted special applications. Responding to the offer of a papier-mâché piece by the French doctor Louis Auzoux, Döllinger stated that good models could give school

N-I-25, Polizei-Direktion München to Präsident der Regierung von Oberbayern, 2 Mar. 1849.

${ }^{17}$ Richardson, op. cit., note 2 above; Sappol, op. cit., note 2 above; Sean Burrell and Geoffrey Gill, 'The Liverpool cholera epidemic of 1832 and anatomical dissection: medical mistrust and civil unrest', J. Hist. Med. Allied Sci., 2005, 60: 478-98.

${ }^{18}$ On the eighteenth century, see Stukenbrock, op. cit., note 2 above. On the nineteenth, see, for Döllinger's previous university, Mirjam Elze, 'Die Geschichte des anatomischen Institutes in Würzburg von 1582 bis 1849', dr med. diss., Universität Würzburg, 1990, pp. 97-100, 142-9; and Georg Feser, 'Das anatomische Institut in Würzburg 1847-1903', dr med. diss., Universität Würzburg, 1977, pp. 20-4; and further Werner Piechocki, 'Zur Leichenversorgung der halleschen Anatomie im 18. und 19. Jahrhundert', Acta historica Leopoldina, 1965, 2: 67-105; Gert-Horst Schumacher and Heinzgünther Wischhusen, Anatomia Rostochiensis. Die Geschichte der Anatomie an der 550 Jahre alten Universität Rostock ..., Berlin, Akademie-Verlag, 1970, pp. 178-94; Klaus D Mörike, Geschichte der Tübinger Anatomie, Tübingen, Mohr (Siebeck), 1988, pp. 37-9, 61-9; Silke Wagener,
،“... wenigstens im Tode der Welt noch nützlich und brauchbar ...". Die Göttinger Anatomie und ihre Leichen', Göttinger Jahrbuch, 1995, 43: 63-90; and Buklijas, op. cit., note 2 above, especially pp. $68-70$.

${ }^{19}$ Archiv der Bayerischen Akademie der Wissenschaften (hereafter BAW), XII 274 (hereafter BAWZ), Schneider, 'Aufschlüsse', 14 July 1849.

For attitudes, see ibid., Generalkonservator Friedrich Thiersch to Staatsministerium des Innern für Kirchenund Schulangelegenheiten (i.e., Kultusministerium), 23 Jan. 1849; and Anon., Neueste Nachrichten aus dem Gebiete der Politik, 23 Aug. 1848, no. 137, 1491-2. Franziska Maria Anna Zeiller, geb. Elser, 'Die naturnachahmende Bildnerkunst, insbesondere die nachbildende Darstellung des menschlichen Körperbaues und ihre Bedeutung für Wissenschaft, Kunst und allgemeine Bildung ...', Frankfurter Reform, 17 June 1864, no. 71, 8-page 'Extra-Beilage', p. 5 , argued that the prospect of dissection was most painful to the poor, with their physical understanding of resurrection.

${ }^{20}$ Schneider, op. cit., note 16 above, pp. $30-1$ :

"Wachspräparate". 


\section{Models, Dissection and the Revolution of 1848}

pupils and laypeople an idea of the structure of the human body, but not "that exact and secure knowledge" required by physicians and surgeons. "There is only one means by which the medic can be instructed in anatomy, and this is that by dissecting corpses he convince himself of the position and construction of the parts". A teacher might wish to use models, for example, to demonstrate structures as they appeared in life, but only those made under his own supervision, so that, in combination with natural preparations, they would achieve his specific purpose. ${ }^{21}$ Schneider endorsed a similar stance: mere "illustrations of the normal human structure are always superfluous at larger anatomical institutes such as ours". 22 The keyword was "normal", for, welcoming other models, he had noted that "artificial reproductions of anatomical preparations should never be lacking in a well-appointed anatomical cabinet ... and especially in pathological anatomy deserve to be preferred to drawings". ${ }^{23}$ Schneider valued models of specimens that were too fragile to preserve or of which important properties, notably colour, would not survive drying or storage in spirits. The main limitation was funds, for which as early as 1834 he had appealed to "the high sense of our illustrious monarch for art and science". 24

Zeiller claimed that Döllinger searched for ten years for a modeller in vain. ${ }^{25}$ Even in Munich, a major art centre with a rich waxworking tradition, it was not easy to find someone suitable. The city offered other rich opportunities, including the studios of the painter of religious frescos Peter Cornelius and the sculptor Ludwig Schwanthaler, and anatomical work would usually have struck even the many struggling artists as too constrained, low-status and distasteful. ${ }^{26}$ Nor did the overly theoretical anatomy lectures at the Academy of Arts encourage pupils to engage more deeply; Dr Wimmer, the physician who gave them, cut a "ridiculous" figure. ${ }^{27}$ The academy was, in any case, overwhelmingly oriented towards history painting; modelling was hardly taught. Wax was an

${ }^{21}$ BAW, VII 150 Nr 6, 'Bericht der mathematischphysikalischen Klasse ...', 13 Aug. 1836: “jene genaue und sichere Kenntniß ... Es gibt nur ein Mittel, wie der Mediciner in der Anatomie unterrichtet werden kann, und dieses ist, daß er sich durch Seciren an Leichnamen von der Lage und Beschaffenheit der Theile selbst überzeuge". On Auzoux, see the works cited in note 6 above.

${ }^{22}$ UAM, N-I-21, faculty circular, 16 Nov. 1844 : "Abbildungen des normalen Baus des Menschen an größeren anatomischen Anstalten, wie die hiesige ist, in jedem Falle überflüssig sind.'

${ }^{23}$ Ibid., N-I-17, 'Die künstlichen Wachsbildungen anatomischer Präparate durch Dr. [Félix] T[h]ibert in Paris u. [C W] Fleischmann in Nürnberg betreffend', Apr. 1841: “daß solche künstliche Nachbildungen anatomischer Präparate in einem wohleingerichteten anatomischen Kabinete nie fehlen sollen ... und vorzüglich in Beziehung auf pathologische Anatomie vor den Zeichnungen den Vorzug verdienen." For a negative response to the same offer, see Elze, op. cit., note 18 above, p. 97.
${ }^{24}$ Schneider, op. cit., note 16 above, p. 30: “dem hohen Sinne unsers erhabenen Monarchen für Kunst und Wissenschaft". All emphasis is in the originals.

${ }^{25}$ Paul Zeiller, Neue Münchener Zeitung, Beilage of 8 June 1849 to no. 133 of 7 June.

${ }^{26}$ Mazzolini, op. cit., note 1 above, pp. 52-3. On the art scene, see Sheehan, op. cit., note 13 above; and, more generally, Andrew Hemingway and William Vaughan (eds), Art in bourgeois society, 1790-1850, Cambridge University Press, 1998, pp. 201-88. Zeiller did some paintings for churches; see L N, '†Paul Zeiller', Der Komet, 1893, no. 431, consulted as a copy in Münchner Stadtmuseum, Puppentheatermuseum, 'Schst. Zeiller'.

${ }^{27}$ Bayerisches Hauptstaatsarchiv (hereafter BHSA), MK 51439 (hereafter BHSAA), Academy director W Kaulbach to Kultusministerium, 18 Nov. 1854: "den Anschein des Lächerlichen gewonnen hat". See further Eugen von Stieler, Die Königliche Akademie der bildenden Künste zu München 1808-1858 ..., Munich, Bruckmann, 1909, especially pp. 54, 110, 134. 


\section{Nick Hopwood}

important south German industry, its major client the Catholic church, but did not count as Art. ${ }^{28}$

So, among academically trained artists, Paul Zeiller was unusual in combining a special interest in anatomy with experience using wax. The son of a merchant in Ehingen on the Danube at the foot of the Swabian Alb, after elementary school he attended the local Latin school and was then apprenticed to a chandler (Wachszieher). Zeiller would probably have learned to make ex votos as well as candles, but not the elaborate figures and reliefs that were the preserve of more highly skilled Wachsbossierer. Soon, however, his artistic talent persuaded his mother to send him to the Augsburg Art School (since 1835 part of the Polytechnic School), a feeder institution for the Munich academy, where in 1840 he progressed to study painting. In 1843 he married Franziska or Fanny Elser (1819-81), a physician's daughter from a nearby Württemberg town (Figure 2) ${ }^{29}$ Through her father, who had directed an asylum until his death in 1837 , Zeiller claimed to have become curious about brain anatomy, ${ }^{30}$ and this may have inspired him to attend lectures by Schneider and Förg. ${ }^{31}$

From 1844 the anatomists taught Zeiller to model. The artistic Erdl took the lead "through his own instruction" in introducing him to "the finer points". Dissections by Schneider and Förg provided additional material from which to work. " "I had ... every time to make two natural preparations, the one to shape the plaster mould, the other as a pattern", Schneider recalled. ${ }^{33}$ For life-size models, Zeiller formed moulds directly on the tissue, and then finished and painted wax casts to match the patterns. He began with a demountable model of a human brain, ${ }^{34}$ but highly magnified embryological models were his major early success.

Following Döllinger's developmental approach, Erdl was drawing and engraving plates of human and chick development big enough to be seen in class. Though in the first place for medics, he offered the soon-standard atlas, with open religiosity rare in German embryology, to all who would "worship and adore the omnipotence, wisdom and goodness of the creator through the contemplation of his works". ${ }^{35}$ Zeiller made thirty "tables" or "boards" in human embryology, from the female sex organs through oogenesis and early

\footnotetext{
${ }^{28}$ Reinhard Büll, Das große Buch vom Wachs. Geschichte, Kultur, Technik, 2 vols, Munich, Callwey, 1977; Wachszieher und Lebzelter im alten München. Sammlung Ebenböck ..., Munich, Münchner Stadtmuseum, 1981.

29 'Ehren-Buch der Familie Paul Zeiller II ...', c.1918, in the possession of Frau Elsbeth Schramm, Rathausstraße 5, 82031 Grünwald; Archiv der Akademie der Bildenden Künste München, 'Matrikelbuch', 1809-41, no. 3061.

${ }^{30}$ Paul Zeiller, Enthüllungen über die Sektion und die Todesart Seiner Majestät König Ludwig II. von Bayern ..., Munich, im Selbstverlage, 1887, pp. 14-15; and, more fully, Freies Deutsches Hochstift, Frankfurt am Main (hereafter FDH), idem, 'Vortrag über die mangelhafte Section Sr Maj. König Ludwig II' [1887]. On Andreas Elser, see [Rudolf] Camerer and [Emil] Krimmel, Geschichte der Königl.
}

württembergischen Heilanstalt Zwiefalten 1812-1912 ..., Stuttgart, Greiner \& Pfeiffer, 1912

${ }^{31}$ For attendance, see N, op. cit., note 26 above.

${ }^{32}$ BAWZ, Thiersch to Kultusministerium, 'Die Sammlung', 21 Apr. 1848 (office copy): "durch eigne Anleitung ... die Feinheiten”. Paul Zeiller, Führer durch die Säle des anthropologischen Museums ..., Munich, 1862, p. 6, counts eighteen years in the field.

${ }^{33}$ BAWZ, Schneider to Generalkonservatorium, 5 Apr. 1848: "mußte ich ... jedesmal zwei natürliche Präparate machen, das eine zur Bildung der Gypsform, das andere zum Nachbilden".

${ }^{34}$ Zeiller, 'Vortrag', op. cit., note 30 above.

${ }^{35} \mathrm{M} P$ Erdl, Die Entwickelung des Menschen und des Hühnchens im Eie ..., vol. 1: Entwicklung der Leibesform, part 1: Entwicklung der Leibesform des Hühnchens, Leipzig, Voss, 1845, p. vi: "die Allmacht, 


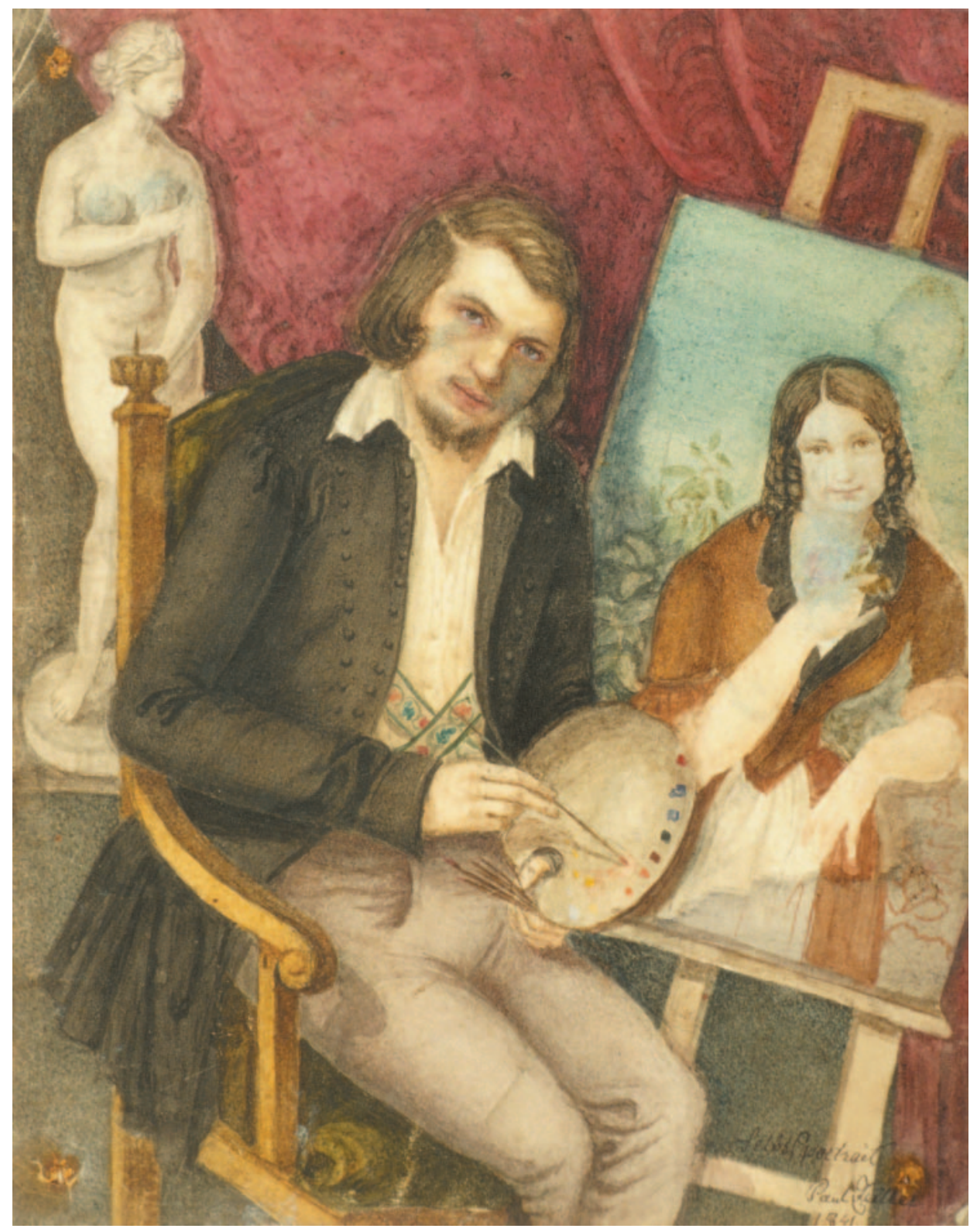

Figure 2: "Self-portrait" of Paul Zeiller in 1841, when he was a student of painting at the Munich Academy of Arts and presumably already engaged to Fanny Elser. The characteristically Biedermeier work looks to his future as painter and husband, not modeller or sculptor, let alone anatomist. Elser's pose echoes that of the statue in the background; Zeiller thus shows himself painting his own Venus. From 'Ehren-Buch der Familie Paul Zeiller II', c.1918, courtesy of Elsbeth Schramm. Original dimensions $c .19 \times 15 \mathrm{~cm}$. 


\section{Nick Hopwood}

development to birth, with special tables on the development of the head and external genitalia. A far cry from Auzoux's robust equipment to take apart and put together again, "each forms a very elegantly presented cassette, with a velours base, on which the preparations lie, and a glass cover over it". ${ }^{36}$ Zeiller's waxes sound closer to rarities for aristocratic collections than resilient aids for professional science. They were not just materially linked to the trade in religious accessories; Erdl's natural theology made them devotional objects in their own right.

Zeiller was also employed in the midwifery school, which taught an average of fifty-five midwives a year. The new director Anselm Martin had planned to import drawings from a new Prussian textbook, but since Berlin would not release them without text, he had Zeiller produce plates using the school's collection. Martin then asked him to make wax preparations of the development of the egg through pregnancy; these gave a "round picture", "more real" and easier to remember than flat drawings. ${ }^{37}$ With the institute of obstetrics, in which discipline models were also long established, the school became a crucial centre of support. The aging, conservative obstetrics professor, Johann Baptist Weissbrod, still inclined towards the Romantic nature philosophy of his youth, would be Zeiller's most powerful and steadfast patron. ${ }^{38}$

These arrangements were informal, but then "anatomical modeller" was not a regular occupation. Medical models were made by artists, preparators and others. Most German universities had a drawing teacher, but professors' attempts to create posts for scientific artists tended to founder on the combination of demanding job description and low academic and artistic status. ${ }^{39}$ Models were more of a luxury than drawings and the skill was less widely distributed. Some state collections already employed staff to prepare specimens for display-Munich's zoological preparator had a doctorate ${ }^{40}$ - but it was rare for a medical modeller to gain a dedicated position, such as Joseph Towne enjoyed at Guy's. In Vienna Dr Anton Elfinger was from 1849 hired by the medical faculty to produce illustrations and models, but the money soon ran out. A little later at the University of

Weisheit und Güte des Schöpfers durch die Betrachtung seiner Werke anzubeten und zu verehren".

${ }^{36}$ Bibliothek der Anatomischen Anstalt der Ludwig-Maximilians-Universität München, A654, Anton Foerg, 'Catalog der embryologischen Wachspräparatensammlung der Universitaet. Angefertigt unter der Leitung des verstorbenen Prof. Dr. Erdl von Herrn Praeparator Paul Zeiller', preface of 1 Feb. 1851: "Die Sammlung besteht aus 34 [originally 30] tabulis; von denen jede eine sehr elegant ausgestattete Cassette bildet, mit wollsammterm Grunde, auf welchem die Präparate liegen, und eine Glassturze über dieselbe."

${ }^{37}$ Anselm Martin, Geschichte und Lehr-Methode der k. Hebammen-Schule, dann Jahresbericht der Gebär-Anstalt zu München ..., Munich, 1848, pp. 27-8, 41; Paul Zeiller, Hand-Atlas für Hebammen. Nebst beschreibender Erklärung, 2nd ed., Munich, Joh. Palm's Hofbuchhandlung [1852], pp. i-iii (reference to a first version completed in 1846), 106 ("mit dem wirklicheren ... runden Bilde"); Juliane C Wilmanns,
'Die klinische Ausbildung der Hebammen und ihre Bedeutung für das Hebammenwesen im Bayern des 19. Jahrhunderts', in Hans Schadewaldt and Jörn Henning Wolf (eds), Krankenhausmedizin im 19. Jahrhundert ..., Munich, Münchener Vereinigung für Geschichte der Medizin, 1983, pp. 145-57, especially pp. 148-51. See further Susanne Preußler, Hinter verschlossenen Türen. Ledige Frauen in der Münchner Gebäranstalt (1832-1853), Munich, Münchner Vereinigung für Volkskunde, 1985.

${ }^{38}$ [Albert] Döderlein, 'Die UniversitätsFrauenklinik', in von Müller (ed.), op. cit., note 14 above, pp. 237-41; Urs Boschung, 'Geburtshilfliche Lehrmodelle. Notizen zur Geschichte des Phantoms und der Hysteroplasmata', Gesnerus, 1981, 38: 59-68; Schnalke, op. cit., note 1 above, pp. 55-8.

${ }^{39}$ Schulze, op. cit., note 8 above, pp. 105-25.

${ }^{40}$ Almanach der königlich bayerischen Akademie der Wissenschaften für das Jahr 1845, p. 46; Köstering, op. cit., note 8 above, pp. 153-83. 


\section{Models, Dissection and the Revolution of 1848}

Freiburg in Baden Dr Adolf Ziegler made embryological waxes as a zootomical Assistent, a position that for others was a stepping-stone to a chair, but from which he resigned in 1868 to build up a private studio. ${ }^{41}$

Zeiller's appointment is always presented as a personal act of the king, who was said to be proud to own a collection as distinctive as those in Vienna and Florence. ${ }^{42}$ The letter came in July 1847 from Ludwig's favourite spa, where, at the height of the love affair that would cost him the throne, he was staying with the "Spanish" dancer "Lola Montez". With effect from 1 October, Zeiller was appointed "preparator" at an annual salary of 600 guilders. He committed himself for at least ten years to working four hours per morning, though on Sundays and holidays only in urgent cases, "diligently, honestly and conscientiously on the making of preparations in wax, plaster or papier mâché for the anatomical institute" under the supervision of its director or some other expert. ${ }^{43}$ The well-connected prodigy Erdl surely played an important role, and Weissbrod as rector, or head of the university for the year, pushed the appointment through without much consultation. Schneider's reservations seem to have been ignored, perhaps because, without the membership of the Academy of Sciences that Erdl enjoyed, and as only acting director, he lacked status. For Weissbrod, "[t]he outstanding advantage of ... art treasures", than which, it was testified from Paris, "there has never existed anything more perfect of this kind', is clear for all to see; they serve extraordinarily to facilitate and to reinforce for the students one of the first and most important elementary sciences of medicine ... With most joyful heart, therefore, I announce this most gracious decree of our most merciful King". Weissbrod also reported approval for the purchase of Zeiller's embryological collection. Preparator and professors looked set to collaborate in bringing the medical faculty "extraordinary celebrity". ${ }^{44}$

In Paris, Zeiller's models were admired in the new museum of comparative anatomy at the School of Medicine, which was hailed as expanding horizons beyond clinical practice and opening a "new era" of progress for that institution. ${ }^{45}$ This praise reinforced Bavarian admiration for work that seemed so fittingly to marry science, art and religion. Yet the models were potentially problematic too: aesthetic appeal was valued over sturdiness and craft over direct investigation of nature. This, at least, is where critics would attack. For hardly had Zeiller been appointed than decades of conflict began.

\footnotetext{
${ }^{41}$ Schnalke, op. cit., note 1 above, pp. 63-7, 79-82; Hopwood, op. cit., note 6 above, pp. 17-22.

${ }^{42} \mathrm{~N}$, op. cit., note 26 above.

${ }^{43}$ BAWZ, Ludwig to senate, 8 July 1847 (copy): "Präparator ... zur Anfertigung von Präparaten in Wachs, Gyps oder papier maché für die anatomische Anstalt dahier fleißig, redlich und gewissenhaft $\mathrm{zu}$ arbeiten".

${ }^{44}$ Weissbrod, 'Fortsetzung des ... UniversitätsArtikels', Münchener politische Zeitung, 14 July 1847 , 48, no. 166, 665: “"jamais il n’a existé quelque chose de plus parfait dans ce genre'... Der vorzügliche eminente Nutzen solcher Kunstschätze liegt klar vor Augen; sie dienen ja einer der ersten und wichtigsten
}

Elementarlehren, der Medicin ... den Studirenden außerordentlich zu erleichtern und zu befestigen. Mit freudigstem Herzen verkünde ich daher diese huldvollste Verfügung unsers allgnädigsten Königs ... eine ausgezeichnete Celebrität". Schneider had expressed his view through the faculty at the end of May 1847: BAWZ, Schneider to Generalkonservatorium, 5 Apr. 1848

${ }^{45}$ Anon., 'Feuilleton: Musée d'anatomie comparée à l'école de médecine', Gazette médicale de Paris, 2nd series, 1845, 13: 693-705, on pp. 702-4: "ère nouvelle". Weissbrod quoted from here. See further Lemire, op. cit., note 1 above, p. 336. 


\section{"The Proletariat Could Find in His Preparations Protection for Their Corpses"}

Zeiller now had the security to assert himself, but with Erdl terminally ill from late 1847, Zeiller's key relationship was with Schneider, director in his own right at last, whose objections turned out to be serious. Anatomist and artist soon struggled inseparably over Zeiller's status - did he have the right to control his own working time? - and the value of models. Their positions polarized when the 1848 revolution sharpened and widened the controversy. As a ferment of proposals, including for popular science, social medicine, university democracy and laboratory disciplines, linked medical and scientific to more general political reform, ${ }^{46}$ Zeiller announced that models should replace dissection and Schneider that they had no role in a university at all. How did it come to this, and what were the politics of the controversy?

Zeiller at first had easy access to natural preparations and the models and moulds he produced, and an extraordinarily free hand in ordering materials. Since the afternoons were his own, and he was allowed to sell copies of waxes he made for the university, it could easily become unclear what was owed to whom. This was unacceptable to Schneider, who had taken "the inconvenient and uninvited guest" into the overcrowded institute only when the hospital refused. ${ }^{47} \mathrm{He}$ doubted that the university would get its money's worth and worried that Zeiller needed more supervision. In late 1847 the senate approved new regulations stipulating that Zeiller must model only after preparations his superior had made or approved, keep a journal for both to sign at the end of every month, and hand over models and moulds. ${ }^{48}$ This would severely limit Zeiller's independence and ability to produce copies.

Schneider watched Zeiller closely while a distinctively Bavarian version of the European revolution unfolded around them. The Montez affair had already forced Ludwig to replace a long-serving conservative cabinet with liberals. In February and March 1848 he had to concede so much that on 20 March he chose to abdicate rather than forfeit real power. Germany's most autocratic monarch was the only one to go. Change was limited — his son took over as Maximilian II—but the spring and summer air was heady with plans for reform. ${ }^{49}$ Zeiller was already on a collision course with Schneider, but it is

\footnotetext{
${ }^{46}$ Wolfgang König, Universitätsreform in Bayern in den Revolutionsjahren 1848/49, Munich, Beck, 1977; Timothy Lenoir, 'Laboratories, medicine and public life in Germany, 1830-1849: ideological roots of the institutional revolution', in Andrew Cunningham and Perry Williams (eds), The laboratory revolution in medicine, Cambridge University Press, 1992, pp. 14-71; Arleen Marcia Tuchman, Science, medicine, and the state in Germany: the case of Baden, 1815-1871, Oxford University Press, 1993, pp. 91-112; Andreas W Daum, Wissenschaftspopularisierung im 19. Jahrhundert. Bürgerliche Kultur, naturwissenschaftliche Bildung und die deutsche Öffentlichkeit, 1848-1914, Munich,
}

Oldenbourg, 1998; idem, 'Science, politics, and religion: Humboldtian thinking and the transformations of civil society in Germany, 1830-1870', Osiris, 2nd ser., 2002, 17: 107-40; Constantin Goschler, Rudolf Virchow. Mediziner-Anthropologe-Politiker, Cologne, Böhlau, 2002, pp. 58-92.

${ }^{47}$ BAWZ, Thiersch to Kultusministerium, 'Das ordnungswidrige Betragen', 21 Apr. 1848 (office copy): "den unbequemen u. ungebetenen Gast".

${ }^{48}$ These rules of 29 Dec. 1847 are clear from ibid., Schneider to Generalkonservatorium, 5 Apr. 1848.

${ }^{49}$ Rainer Schmidt, 'In revolutionärer Unruhe 18301848 ', in Boehm and Spörl (eds), op. cit., note 13 above, pp. 251-70; Karl-Joseph Hummel, München in der 


\section{Models, Dissection and the Revolution of 1848}

surely no coincidence that open confrontation erupted two weeks after Ludwig lost his crown. The revolution gave Zeiller the confidence to resist and a vocabulary in which to do so.

Schneider had heard rumours, in part from the anatomy attendant, a Mr Höß, that Zeiller was getting ready to sell abroad preparations he should have been making for the university. So Schneider, also being pestered by Zeiller's creditors, arranged to show two professors from the administration committee that purchased items were present and correct. They arrived at 11.00 a.m. on Monday 3 April to find Zeiller absent, pleading an eye inflammation, but Höß discovered him at home packing models. When Zeiller appeared-perfectly well, Schneider said — and opened his room with the only key, the professor had to admit that the models were mostly there, if not all finished, and that those to be sent out were copies. Schneider tried to take custody of the moulds, patterns and completed models, but Zeiller refused to give them up. ${ }^{50}$

The row came to a head the next day when Schneider and Zeiller were supposed to review his work for March and sign the book. Schneider found Zeiller taking a mould from a cross-section of brain, and remonstrated that without his knowledge it was illegal for Zeiller to open any cadaver. To which, in the presence of three witnesses, Zeiller replied, "with a rudeness I have never experienced before ... that he did not recognize any laws, the time was now past for being bound by laws, freedom prevails- he could now do what he wanted". No one gave him orders, he was employed in the institute just like the professor and had the same rights. "He had noticed for a long time that I limited and cramped him, now he was making himself free, he did not need me any more, I had just represented everything incorrectly, he wanted to prove and have investigated by a commission that I had made 16 to 18 mistakes on the preparations, then he would show me." As Zeiller cursed, Schneider tried to enforce rules he must have largely devised, while presenting himself as the mere agent of a higher power. Schneider finally asked Zeiller to give him the finished models, "so as to be able to store them, according to the order of the high academic senate, in the designated glass cupboard of the cabinet. He repeatedly refused to give them up with the remark that he would not have his preparations displayed in a kitchen cupboard, he would display them how he wanted." Schneider felt his authority so undermined that he left the institute and would not return until his official standing was restored. It was impossible, he argued, to supervise a man who was "not honest" with the university. ${ }^{51}$

Revolution von 1848/49, Göttingen, Vandenhoeck \& Ruprecht, 1987; David Blackbourn, The Fontana history of Germany, 1780-1918: the long nineteenth century, London, Fontana, 1997, pp. 138-73.

${ }^{50}$ BAWZ, Schneider to Generalkonservatorium, 5 Apr. 1848. When Erdl fell ill, he had, to Schneider's annoyance, let Zeiller use his room plus kitchen: ibid., Schneider to Thiersch, 6 Dec. 1847. Towne also insisted on his own space: Schnalke, op. cit., note 1 above, p. 64.

${ }^{51}$ BAWZ, Schneider to Generalkonservatorium, 5 Apr. 1848: "mit einer noch nie erlebten Rohheit ... 'daß er keine Gesetze kenne, die Zeit sei jetzt vorüber wo man sich an Gesetze binde, Freyheit besteht,- - er könne jetzt thun was er wolle. ... Er hätte es schon lange bemerkt daß ich ihn beschränke und beenge, jetzt mache er sich frei, er brauche mich nicht mehr, ich hätte ihn so nur alles fehlerhaft dargestellt, er wolle mir 16 bis 18 Fehler an den Präparaten nachweisen und von einer Kommission prüfen lassen, da werde er es mir schon zeigen.' ... um dieselben den [sic] Auftrag des hohen akademischen Senates gemäß in den bezeichneten Glasschrank des Kabinets aufbewahren zu können. Diese Abgabe verweigerte er abermals mit dem Bemerken, daß er seine Präparate nicht in einen Küchenschrank 


\section{Nick Hopwood}

Schneider reported to the "general conservator of the scientific collections of the state", the main mediator between the anatomical institute and the recently established Ministry for Religious and Educational Affairs. From March 1848 this was the new academy president, classical philologist and moderate liberal Friedrich Thiersch. Since he had also succeeded Weissbrod as rector, in these critical months all academic decisions passed across at least one of his desks. To allow Schneider back into the institute, Thiersch immediately barred Zeiller pending the decision of a commission of three academicians. They told him to recognize Schneider and keep within the regulations, but argued in mitigation that the "excellent artist", not easily replaced, had genuinely misunderstood the rules. ${ }^{52}$ Schneider still wanted him out, and Thiersch was keen to reduce strife in the congested institute. ${ }^{53}$ In June the minister ruled that Zeiller was too low-status for a decision from him, but that the modeller should stay. ${ }^{54}$ Schneider's protest justified continuing the exclusion, and based on one charge or another it remained in force (with Zeiller on full pay) for some sixteen months. ${ }^{55}$

The same protagonists fought that winter and spring over the purchase of the embryological models that Zeiller insisted had been promised through Weissbrod in July $1847 .{ }^{56}$ The medical faculty was divided: Schneider expressed misgivings but Weissbrod, now as dean, eventually secured agreement that they wanted the collection, provided the academy would pay. ${ }^{57}$ In an unusually rich report delayed until after the incident of 4 April 1848, Thiersch drew on Schneider's views to advise against purchase. Noting the lack of space and that Zeiller could always be asked to remake the collection, he then rehearsed the division of expert opinion. While some admired wax preparations as "true works of art ... and an excellent aid for teaching and for scientific research", for others they were "scientifically quite without value or only in their embryological parts of some significance", and of little pedagogical use. They were "only more or less adequate copies" of the natural objects, the dead body and preparations made from it, with which research was concerned, and to which students should be led. Models preserved clinical pictures, especially their colours, more effectively than specimens in spirits-but exact drawings and coloured engravings did so more definitely and permanently. Models were too fragile for regular use. Worse,

such preparations could as little be called art works as the dressed wax figures that are put on show at fairs. They did not demand fine formation and brilliant shaping of nature, only through which a product of technical skill would become a work of art, but an exact as possible imitation and reproduction of that which nature shows, as would be found in the practice of any craft employing a higher technique. If such collections nevertheless not infrequently enjoyed exceptional admiration

aufstellen lasse, er stelle sie auf wie er wolle. ... mit uns nicht redlich meint."

${ }^{52}$ Ibid., Thiersch to Zeiller, 6 Apr. (office copy), Thiersch to commission, 7 Apr., commission minutes, 17 Apr. 1848: "ein ausgezeichneter Künstler".

${ }^{53}$ Ibid., Thiersch to Kultusministerium, 'Das ordnungswidrige Betragen', 21 Apr. 1848.

${ }^{54}$ Ibid., Kultusministerium to senate, 19 June 1848 (copy): "nachdem Wachspraeparator Zeiller als dem höheren Personale der Staatsdiener angehörig nicht erachtet werden kann".

${ }^{55}$ Ibid., Kultusminister Friedrich Ringelmann to Generalkonservatorium, 25 Aug. 1849; Paul Zeiller, Münchener Anzeiger, Beilage zu den Neuesten Nachrichten, 10 Mar. 1849, no. 50, 373 (full pay).

${ }^{56}$ Zeiller, op. cit., note 25 above.

${ }^{57}$ UAM, N-I-24, Weissbrod to senate, 26 Nov. 1847 (draft). 


\section{Models, Dissection and the Revolution of 1848}

and acclaim, this came in general from the side of the curious and thus of the easily fooled crowd, which like children delight in the fine material, in the resulting delicacy and smoothness of form and the shine of the pure and shimmering colours, unconcerned by the inner emptiness and insignificance of the object.

Echoing disparagement of instrument-makers and experimentalists, Thiersch rejected modelling as merely artisanal work, and models as deceiving only those lacking in scientific and artistic judgement. He concluded that, not even proper art, wax preparations "lie beyond the sphere of strict scientificity ... as a not exactly unwelcome luxury object" the state could ill afford. ${ }^{58}$ In early May the ministry decided not to buy. ${ }^{59}$

That summer calls for social reform directed new attention to dissection of the poor as a form of inequality after death, and so made anatomy more generally controversial. On 2 August the carpenters' guild almost forced open a coffin to reassure themselves that the journeyman they planned to bury was inside, and Munich's new liberal newspaper, the Neueste Nachrichten, reported that two days later mourners at the burial of the butcher's journeyman Paul Neumair were outraged by a scandal, "which human feeling does not permit us to describe". ${ }^{60}$ On 23 August the paper asked, "Is it justified to give up the corpses of the destitute without their prior consent to a despotic and for most people horrible fate? Not enough, that in hospital ... the poor must mostly perish without friend or relative; no, the thought ... of the imminent mutilation of their body must fill their last hour with double agony." It was acceptable to dissect criminals, suicides, volunteers and those whose bodies had been bought during their lives, but dissection merely for being unable to afford a burial was "a glaring injustice". Science should not fear reform, for surely its practitioners would give their own bodies-except that they did not and the university bought out any student corpses at risk of dissection. In the past the poor not only worked hardest in life, but were also tortured by the prospect, which they feared more, of being "butchered to pieces" after death, especially the women, for whom modesty was also

\footnotetext{
${ }^{58}$ BAWZ, Thiersch to Kultusministerium, 'Die Sammlung', 21 Apr. 1848: "wahre Kunstwerke ... u. für wissenschaftliche Forschung u. für den Unterricht ... ein vorzügliches Hülfsmittel ... wissenschaftlich ganz ohne Werth oder nur in ihren embryologischen Theilen von einiger Bedeutung ... nur mehr oder weniger genügende Copieen ... könnten solche Präparate Kunstwerke sowenig genannt werden, wie bekleidete Wachsfiguren, die man auf Jahrmärkten zur Schau stelle. Nicht auf feine Bildung u. geniale Gestaltung der Natur komme es dabei an, wodurch allein ein Produkt technischer Fertigkeit zum Kunstwerk werde, sondern auf möglichst genaues Nachbilden u. Wiedergeben dessen, was die Natur zeige, wie es bei jeder Thätigkeit des mit höherer Technik verkehrenden [?] Handwerkes gefunden werde. Wenn gleichwohl solche Sammlungen sich nicht selten eines ausgezeichneten ja bewunderungsvollen Beifalls erfreuen, so geschähe solches gemeiniglich von Seiten der schaulustigen $u$. darum der scheingetäuschten Menge, welche den Kindern gleich sich an dem feinen Material, an der dadurch bedingten Zierlichkeit u. Glätte der Form u. an
}

dem Glanz der reinen u. schillernden Farben ergötzen, unbekümmert um die innere Leerheit $\mathrm{u}$.

Bedeutungslosigkeit des Gegenstandes. ... außer der Sphäre der strengen Wissenschaftlichkeit liegen ... als ein nicht gerade unwillkommenen Luxusgegenstand." For hostility to artisans in the Bavarian Academy of Sciences, see Myles W Jackson, 'Can artisans be scientific authors? The unique case of Fraunhofer's artisanal optics and the German Republic of Letters', in Mario Biagioli and Peter Galison (eds), Scientific authorship: credit and intellectual property in science, New York, Routledge, 2003, pp. 113-31. See further $\mathrm{H}$ Otto Sibum, 'Experimentalists in the Republic of Letters', Sci. Context, 2003, 16: 89-120. For similar criticisms of models, see Lemire, op. cit., note 1 above, pp. 159-60; and Spary, op. cit., note 8 above, pp. 172-3.

${ }^{59}$ BAWZ, Kultusminister Hermann Beisler to senate, 6 May 1848 (copy)

${ }^{60}$ UAM, N-I-25, Polizei-Direktion to Präsident der Regierung, 2 Mar. 1849; Anon., Neueste Nachrichten aus dem Gebiete der Politik, 9 Aug. 1848, no. 123, 


\section{Nick Hopwood}

a concern. In future neither status nor money, but a person's free will, should decide the fate of his or her body. ${ }^{61}$ The anonymous author did not criticize anatomists directly; he targeted the hospital and proposed nothing more radical than giving the poor the money for a coffin. But the institute was vulnerable, and Schneider, who received a threatening letter, argued that Zeiller had stirred the whole thing up. ${ }^{62}$

As the forces of order regrouped, the public pressure on the institute framed the hostilities that flared up again within. In October Schneider had the police investigate Zeiller for deception in passing off the skeleton of a convict sold to a priest as that of a saint. In fact, Zeiller explained, he had been asked for a wax skeleton to clothe as a sign to a relic in the church, and, since he found this ridiculous, had had "my pupils" oblige. He was exonerated but remained excluded. ${ }^{63}$ In early December, as the counter-revolution gained the upper hand and fear of the mob spread, Zeiller dramatically escalated the dispute by attacking the institute's management in letters to Thiersch: the previous attendant, Höß's father, had fed his dogs with human flesh and traded in the remains of the dead, animals were buried with human corpses and the institute supplied the General Hospital with human fat for lighting. Only models could prevent such abuses. As Schneider communicated Zeiller's letter, he asserted "that through his preparations corpses and natural preparations were no longer necessary, and so the corpses of the poor, of the proletariat, could be protected; the director of the anatomical institute was responsible to the people for everything that went on within it, and the proletariat could find in his preparations protection for their corpses". ${ }^{64}$

Proletarians would not necessarily have agreed. In Cambridge, we are told, "the infuriated multitude", storming the Anatomical School to recover the first pauper corpse requisitioned under the 1832 Act, was "still further excited by catching a glimpse of one or more wax models, ... which were such excellent facsimiles that they were taken for real bodies". ${ }^{65}$ But Schneider blamed Zeiller that his institute was "in danger of being attacked and destroyed by the mob" ${ }^{66}$ Schneider also saw his own honour and the cadaver supply threatened, allegedly for the first time. So he and Thiersch hastened to turn Zeiller's charges against him. Thiersch demanded prosecution for calumny of a public institution, ${ }^{67}$ and in

1317: "den zu bezeichnen das menschliche Gefühl nicht erlaubt"; BAWZ, Schneider, 'Aufschlüsse', 14 July 1849.

${ }^{61}$ Anon., op. cit., note 19 above: "Ob man berechtigt sey, die Leichen der Unbemittelten ohne ihre vorherige Einwilligung einer willkürlichen, für die meisten so schauderhaften Verfügung preiszugeben? Nicht genug, daß die Armen im Krankenhause ... meistens ohne Freund und Verwandten dahin scheiden müssen, nein, der ... Gedanke an die nahe

Verstümmelung ihres Körpers muß ihre letzte Stunde noch mit doppelter Qual erfüllen. ... eine grelle Ungerechtigkeit ... des Zermetzelns". The hospital's response: ibid., 27 Aug. 1848, no. 141, 1542.

${ }^{62}$ BAWZ, Schneider, 'Aufschlüsse', 14 July 1849.

${ }^{63}$ Ibid., Zeiller to Generalkonservatorium, 27 Oct. 1848: "meinen Schülern"; Polizei-Direktion München to idem, 18 Dec. 1848.

${ }^{64}$ Ibid., Schneider, 'Aufschlüsse', 14 July 1849: “ "daß durch seine Präparate Leichen u. natürliche
Präparate nicht mehr nöthig seien, u. so die Leichen der Armen, des Proletariats geschützt werden könnten; der Vorstand der anatomischen Anstalt sei für Alles, was darin vorgehe, dem Volke verantwortlich, und das Proletariat könne in seinen Präparaten den Schutz der Leichen finden'”. See also ibid., Thiersch to Schneider, 21 Jan. 1849 (office copy). For claims of similar abuses, see Lemire, op. cit., note 1 above, p. 383.

${ }^{65}$ Quoted in Mark W Weatherall, Gentlemen, scientists and doctors: medicine at Cambridge, 1800-1940, Woodbridge, Boydell, 2000, p. 44.

${ }^{66} \mathrm{BAWZ}$, Thiersch to Kultusministerium, 13 Dec. 1848 (office copy): "in Gefahr sey, vom Pöbel angegriffen u zerstört zu werden"; Schneider, 'Aufschlüsse', 14 July 1849.

${ }^{67}$ Ibid., Schneider, 'Aufschlüsse', 14 July 1849; Thiersch to Kultusministerium, 23 Jan. 1849. 


\section{Models, Dissection and the Revolution of 1848}

January 1849 the senate (with Thiersch now present as prorector) asked the ministry to dismiss him. ${ }^{68}$

Yet medical opinion remained divided. The hospital director expressed satisfaction with Schneider and disgust at Zeiller's "most brazen, most hideous lie". But the obstetrician Martin, though also categorically rejecting the accusations, excused Zeiller as "an artist worthy of real respect", "a man" of "high selflessness", with "a calm and dignified demeanour". The allegations must result from an "injurious relationship" or "a state of passion". ${ }^{69}$ Zeiller, who could not easily model during his suspension, drew on Martin's support for an obstetric atlas dedicated to Weissbrod (Figure 3). ${ }^{70}$

The police disappointed Schneider again; reluctant to take sides in a quarrel, they found no evidence that Zeiller had spread rumours against the institute, though in late October he had reported an angry mood the police could well understand. It had taken considerable effort to avoid more graveyard incidents. "As long as cadavers from the higher classes of society are not also dedicated to anatomy", the report went on, "the lower classes see in the delivery of the corpses of their fellows ... less a scientific purpose than a distinction in rank between classes extending even after death." The poor should be given more chance to claim the bodies of those who died in the hospital and the anatomists should treat these with more respect. The police also considered it insensitive to drive prisoners' remains at dusk from Au to the university along streets much travelled by workers. ${ }^{71}$ Nevertheless, the threat to anatomy appears not to have lasted the winter.

In March and April the Zeiller-Schneider dispute reached the press through unsigned articles that the modeller apparently inspired but did not write. The Neueste Nachrichten played his models off against dissection. "[Zeiller] is said to have got into an insignificant exchange of words over certain demands and presumptions of his superior, which he could not reconcile with his oath of office and his honour as an artist, which incident was used by his personal enemy for long-drawn-out persecution and accusations". But foreign countries would not be spending millions on unnecessary models and Zeiller cost much less.

\footnotetext{
${ }^{68}$ Ibid., Ringelmann to senate, 14 Apr. 1849 (copy); see also Thiersch to Kultusministerium, 23 Jan. 1849.

${ }^{69}$ Ibid., Franz von Gietl to Generalkonservatorium, 27 Jan. 1849 (copy): “die frechste, scheußlichste Lüge"; Martin to idem, 27 Jan. 1849 (copy): "ein recht achtenswerther Künstler, ... ein Mann ... hohe Uneigennützigkeit ... ein ruhiges und würdiges Benehmen ... ein etwa verletzendes Verhältniß ... im Zustande der Leidenschaft".

${ }^{70}$ PaulZeiller, Geburtshülflicher Hand-Atlas, nebst beschreibender Erklärung, Munich, im Verlage des Verfassers, in Commission bei Ch. Kaiser, 1850, pp. vvi. Zeiller also published the much slighter Hand-Atlas zur gerichtlichen Medicin für Geistliche,

Rechtsgelehrte und Aerzte, Munich, im Verlage des Verfassers [c.1850]; and Abbildungen über den Bau des menschlichen Gehirns für Aerzte und Verehrer der Phrenologie mit plastischer Beigabe, Munich, im Verlage des Herausgebers [c.1850]. Several other
}

artists signed plates. Nearly forty years later, c.1890, the obstetric atlas was reissued by Ernst of Leipzig as Die Entstehung, Entwicklung und Geburt des Menschen, targeting an audience ranging from physicians to laypeople; the text was revised, but Zeiller's illustrations were seriously updated only in the 16th (1944) edition.

${ }^{71}$ UAM, N-I-25, Polizei-Direktion to Präsident der Regierung, 2 Mar. 1849: "Inso lange nicht auch Leichname aus höhern Klassen der Gesellschaft der Anatomie gewidmet werden, betrachten die untern Klassen in der Ueberlieferung der Leichen ihrer Standesgenossen ... weniger einen wissenschaftlichen Zweck als eine über den Tod noch hinausreichende Unterscheidung der Standes-Klassen." For similar tensions between anatomists and police, see Elze, op. cit., note 18 above, pp. 147-8; and Buklijas, op. cit., note 2 above, p. 11. 


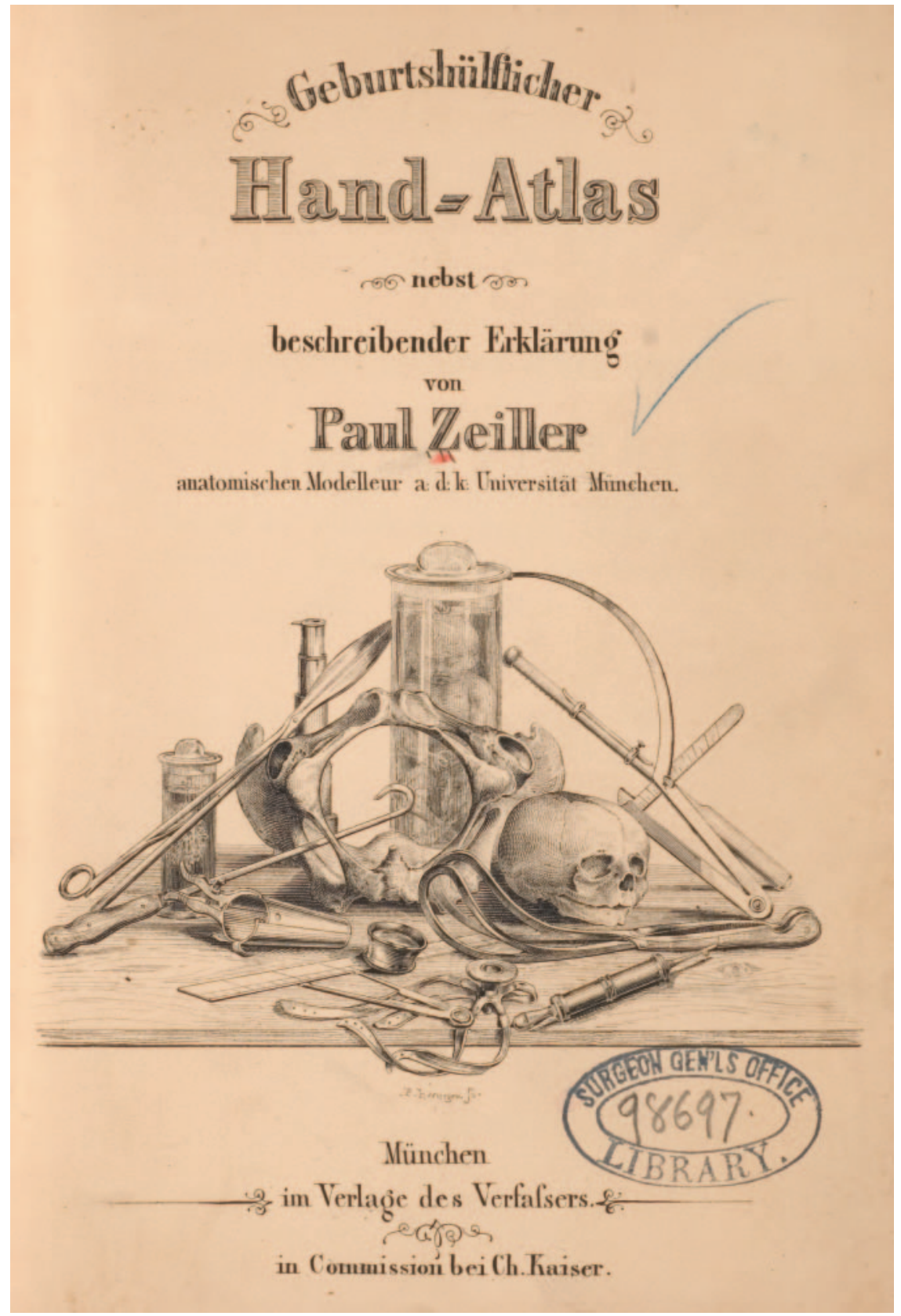

Figure 3: Title-page of Paul Zeiller's obstetric atlas, advertising his university affiliation. The vignette engraved by the Munich artist Peter Herwegen, who also lithographed many of the plates, shows the armamentarium and specimens. From Paul Zeiller, Geburtshülflicher Hand-Atlas, nebst beschreibender Erklärung, Munich, im Verlage des Verfassers, in Commission bei Ch. Kaiser, 1850. Courtesy of the National Library of Medicine. 


\section{Models, Dissection and the Revolution of 1848}

Models were useful in teaching and served the general public as, allegedly, the only means for popular instruction in anatomy and to fulfill "the long-held wish of the working class for equal rights after death, that is, for an honest grave". Social improvement had been an early theme of Max II's reign; this should be offered too. ${ }^{72}$ The case was also discussed in the government-friendly Neue Münchener Zeitung after a series of fairly mild criticisms of anatomical teaching and the institute brought angry rebuttals from Thiersch and Schneider. In response to a question about the fate of Erdl's model collection, Schneider went so far as to assert that this had not been purchased because "wax preparations have neither scientific value nor afford significant advantage in any branch of instruction". Zeiller defended models, not mentioning their potential to replace dissection but accusing Schneider of rejecting what he had earlier praised. ${ }^{73}$

By this time, mid-April, the minister had finally ruled that Zeiller could not be dismissed, since the police had again found no charge to answer, but should work elsewhere. ${ }^{74}$ Though unhappy that the police criticism of the institute was also passed on, Schneider welcomed what he interpreted as a ban on Zeiller. But Zeiller demanded entry "as human being, as citizen", for "[t]he violent oppression of the human spirit would stand in the crassest contradiction with the enlightenment of the year $1849 " .75$ The senate finally reprimanded him for insubordination and he apologized. The ministry clarified that he should work on his own premises - an alpine-style house he had built as a studio on land adjacent to the hospital building where he lived in the early $1850 \mathrm{~s}$ - but that he must have the same access to the institute as anyone else with a bona fide scientific interest. Since Schneider refused to have anything more to do with him, he was supervised by Förg, for whom he was already modelling embryos and brains. ${ }^{76}$ In November 1850 Förg also asked to be relieved of this duty "for ever", and Zeiller was assigned to the dean of the faculty, who delegated the task, mainly to the prosector in pathological anatomy. $^{77}$

The conflict between Zeiller and Schneider was driven by the clashing interests of a modeller and an anatomy professor. Exploiting demand for visual aids, ambitious preparators, artists and technicians were, perhaps rather generally around this time, flexing

\footnotetext{
72 Anon., 'Bekanntmachungen', Münchener Anzeiger, Beilage zu den Neuesten Nachrichten, 1 Mar. 1849, no. 44, 329-30: "Derselbe soll über gewisse Forderungen und Anmaßungen seines Vorstandes, welche er mit seinem Diensteseide und seiner Künstlerehre nicht vereinbaren konnte, in einen unbedeutenden Wortwechsel gerathen sein, welcher Vorfall von seinem persönlichen Gegner zu weitläufigen Verfolgungen und Verdächtigmachungen benützt wurde ... der lange Wunsch der arbeitenden Klasse um gleiche Rechte nach dem Tode, nämlich um ein ehrliches Grab". See also Paul Zeiller, ibid., 10 Mar. 1849 , no. 50, 373, correcting the assertion that he had requested a transfer; and Hans Rall, 'Die politische Entwicklung von 1848 bis zur Reichsgründung 1871', in Spindler, op. cit., note 13 above, pp. 224-82, on pp. 228-38.

${ }^{73}$ Anon., 'Wünsche und Fragen', Neue Münchener Zeitung, 3 Apr. 1849, no. 79, Beilage; 'Erwiederung auf
}

die "Wünsche und Fragen" in der Beilage vom 3. April dieses Blattes', ibid., 20 Apr. 1849, no. 93, Beilage: "wie denn überhaupt Wachs-Präparate weder einen wissenschaftlichen Werth haben, noch in irgend einem Zweige des Unterrichtes erheblichen Nutzen gewähren"; Zeiller, op. cit., note 25 above.

${ }^{74}$ BAWZ, Ringelmann to senate, 14 Apr. 1849

${ }^{75}$ Ibid., Zeiller to Kultusministerium, 24 June 1849 (copy): “als Mensch als Staatsbürger ... Die gewaltsame Unterdrückung des menschlichen Geistes stände mit der Aufklärung des Jahres 1849 im grellsten Widerspruche."

${ }^{76}$ Ibid., Ringelmann to Generalkonservatorium, 25 Aug. 1849; UAM, N-I-27, rector to Förg, 28 Dec. 1848. Förg directed the last four series in Foerg, op. cit., note 36 above, pp. 31-5. On the house, see 'Ehren-Buch', op. cit., note 29 above.

${ }^{77}$ UAM, N-I-27, rector to faculty, 3 ("für immer") and 23 Nov. 1850. 


\section{Nick Hopwood}

their muscles and chafing under unsympathetic directors. ${ }^{78}$ The loose terms of Zeiller's appointment, uncertainty about his status and a divided faculty helped him keep his position, access to the institute and some professorial collaborators even after an unusually public and acrimonious controversy. He and his admirers saw an "artist" who employed "assistants"79 and was entitled to the same respect as a professor. University officials puzzled at the apparently independent actions of a man who behaved like "the director of the cabinet of wax preparations" but on closer examination was only a "worker" within it. ${ }^{80}$ The ministry placed him among the subordinate personnel, and for Schneider he was medically unqualified, an artisan involved in neither science nor art. Conversely, though we tend to think of German professors as all-powerful, Schneider appears unusually weak not just within an institute that because of its multiple uses was difficult to run, but also in the faculty. Confronted with the prospect of medically unsupervised modelling and a threat to his fragile authority, he expanded standard arguments against models to include even Erdl's embryological collection. Thiersch followed Schneider's lead, but some colleagues refused to condemn a modeller who had so recently been so extravagantly praised. Martin enjoyed a productive relationship with Zeiller, without having to house him, and Weissbrod was heavily invested in his appointment.

The dispute started before, but was radicalized by, the revolution, which encouraged Zeiller to assert himself, popularized the language of equal rights and exacerbated, or (if one accepts Schneider's claim) allowed Zeiller to create, tensions between anatomy and the poor. Yet the level of threat to the institute is hard to assess-it seems to have dissipated by spring 1849 - and there is no evidence that he was more generally active politically. Like many artists and artisans active in 1848, Zeiller is difficult to arrange on a simple left-right spectrum. He was supported by the conservative Weissbrod and opposed by the liberal Thiersch. Zeiller's most inflammatory statements mobilize rights claims, including for the poor, but are probably best understood, less as siding with the proletariat, than as placing models positively within a general chorus for improvement. A radical argument could even have helped deflect criticism that his own fragile, elegant preparations represented "an unnecessary luxury", yet another "waste of money" by the profligate Ludwig. Looking back to his early success and appointment, Zeiller would stay loyal to the monarchy, other conservative patrons, the memories of Döllinger and Erdl and a Romantic view of plastic anatomy. ${ }^{81}$ But in fighting for his rights as an artist he pressed demands for independence that no university anatomist would have entertained. Where appropriate, he fell back on arguing for models as supplements; where possible, he continued to challenge dissection.

\footnotetext{
${ }^{78}$ At the Berlin zoology museum in the late 1850 s and the Württemberg natural history cabinet in the 1860 s the preparator and leading taxidermist Philipp Leopold Martin similarly fought for the freedom to pursue outside interests and his own vision of natural history displays; he tried, again like Zeiller, to gain state support for a private museum: Lynn K Nyhart, Modern nature, University of Chicago Press, forthcoming, ch. 2.
}

\footnotetext{
${ }^{79}$ BAWZ, Schneider to Generalkonservatorium, 6 Dec. 1847: "Gehilfen".

${ }^{80}$ UAM, N-I-28, rector to faculty, 29 Mar. 1852:

"der Vorstand des Wachspräparaten-Cabinets ... Arbeiter".

${ }^{81}$ Zeiller, op. cit., note 25 above: "einen unnöthigen Luxus ... eine neue Geldverschwendung”. For Zeiller's loyalty, see also 'Vortrag', op. cit., note 30 above.
} 


\section{An Anthropological Museum Challenges "Knife Anatomy"}

In the reactionary 1850s Zeiller worked for the Munich professors and on his own account for sale to other institutions. ${ }^{82}$ Some modellers were at this time collaborating with specializing scientists, especially in dermatology and embryology. For example, in Freiburg, Zeiller's contemporary Adolf Ziegler modelled to supplement the anatomy professor's embryological atlas, much as Zeiller had worked with Erdl. But Ziegler continued to make wax embryos, helping to create the consensus that, however limited the value of reproducing normal adult anatomy, embryologists could barely manage without models. ${ }^{83}$ Refusing to specialize, Zeiller offered models of the human ear, cranial nerves, brain, heart and eye, a "female statue, half-anatomical" (Figure 4), a globe, busts of an operation and his atlases; he modelled in plaster and wood as well as wax. ${ }^{84}$ Ziegler, a medical doctor but no embryologist, presented himself as not an author but a "plastic publisher"; he exchanged professorial control for the recognition that tied his models to print publication in the discipline. Zeiller, by contrast, claimed to know enough to appear as an author in his own right. ${ }^{85}$ Though a layman, he insisted that, since anatomy was primarily about forms, an experienced artist could work independently. One medical reviewer accepted that he combined "artist and expert in his person", but most of the Munich faculty did not. ${ }^{86}$

Unusually independent too, though presenting herself in a conventionally supporting role, "modeller's wife" Fanny Zeiller also authored models. ${ }^{87}$ Women anatomical modellers, such as Anna Morandi Manzolini and Marie Catherine Bihéron, were prominent in the eighteenth century, and dermatological mouleuses active (in much more subordinate capacities) in the twentieth, but though nineteenth-century women modelled various objects, no ventures into human anatomy have been reported. ${ }^{88}$ Fanny Zeiller accepted that "it is not in the female nature to be able herself to approach the dissected corpse", but insisted that modelling was "a rich field for her fine skills". She concentrated on embryology. 89

\footnotetext{
${ }^{82}$ Embryological models (mainly by Fanny Zeiller?) went to the Muséum d'Histoire naturelle in Paris: Foerg, op. cit., note 36 above, p. 32; Freiburg in Baden: A Ecker, Untersuchungen zur Ichthyologie ..., Freiburg, Wagner, 1857, p. 11; and Kiev: Anon., 'Vermischtes', Bayerische Zeitung, 13 Sept. 1862, 843. For other interest, see Zeiller, op. cit., note 25 above.

${ }^{83}$ Hopwood, op. cit., note 6 above; Schnalke, op. cit., note 1 above.

${ }^{84}$ [F B W] von Hermann (ed.), Katalog der Allgemeinen Deutschen Industrie-Ausstellung zu München im Jahre 1854, Munich, Franz, 1854, p. 31: "weibliche Statue, halbanatomisch".

${ }^{85}$ Zeiller, Geburtshülflicher Hand-Atlas, op. cit., note 70 above, p. v; idem, op. cit., note 32 above, p. 6 .

${ }^{86}$ Sickel, review of Zeiller, Geburtshülflicher Hand-Atlas, Schmidt's Jahrbücher der in- und ausländischen gesammten Medicin, 1854, 81: 257 : "den Künstler and den Sachverständigen"; his verdict on Zeiller's Hand-Atlas für Hebammen, 2nd edn, ibid.,
}

1853, 80: $280-1$, was positive, too, but he doubted midwives would be able to afford or understand it.

${ }^{87}$ Von Hermann (ed.), op. cit., note 84 above, p. 31 :

"Modelleursgattin"; she claimed that Förg supervised her work.

${ }^{88}$ Schnalke, op. cit., note 1 above, pp. 31, 37-9, 122-7, 145-76.

${ }^{89}$ FZeiller, op. cit., note 19 above, p. 8: "wenn auch die weibliche Natur es nicht vermag, der zergliederten Leiche selbst sich zu nahen ... ein reiches Feld für ihre feinen Fähigkeiten". The incomplete series of bird development shown in a recent mounting in Lemire, op. cit., note 1 above, p. 319, is labelled "fecit Fanny Zeiller München". She also made models to illustrate a lecture given earlier at the German Independent Academy: FDH, Franziska Zeiller to [Theobald] Schideck, 30 Aug. 1864. For the claim that she modelled all the nerves, sense organs and embryology in her husband's museum, see X, 'Nochmals Zeiller's Unterrichtssammlung für Menschenkunde', Frankfurter Reform, 9-10 July 1864, nos 80-81, 318, 


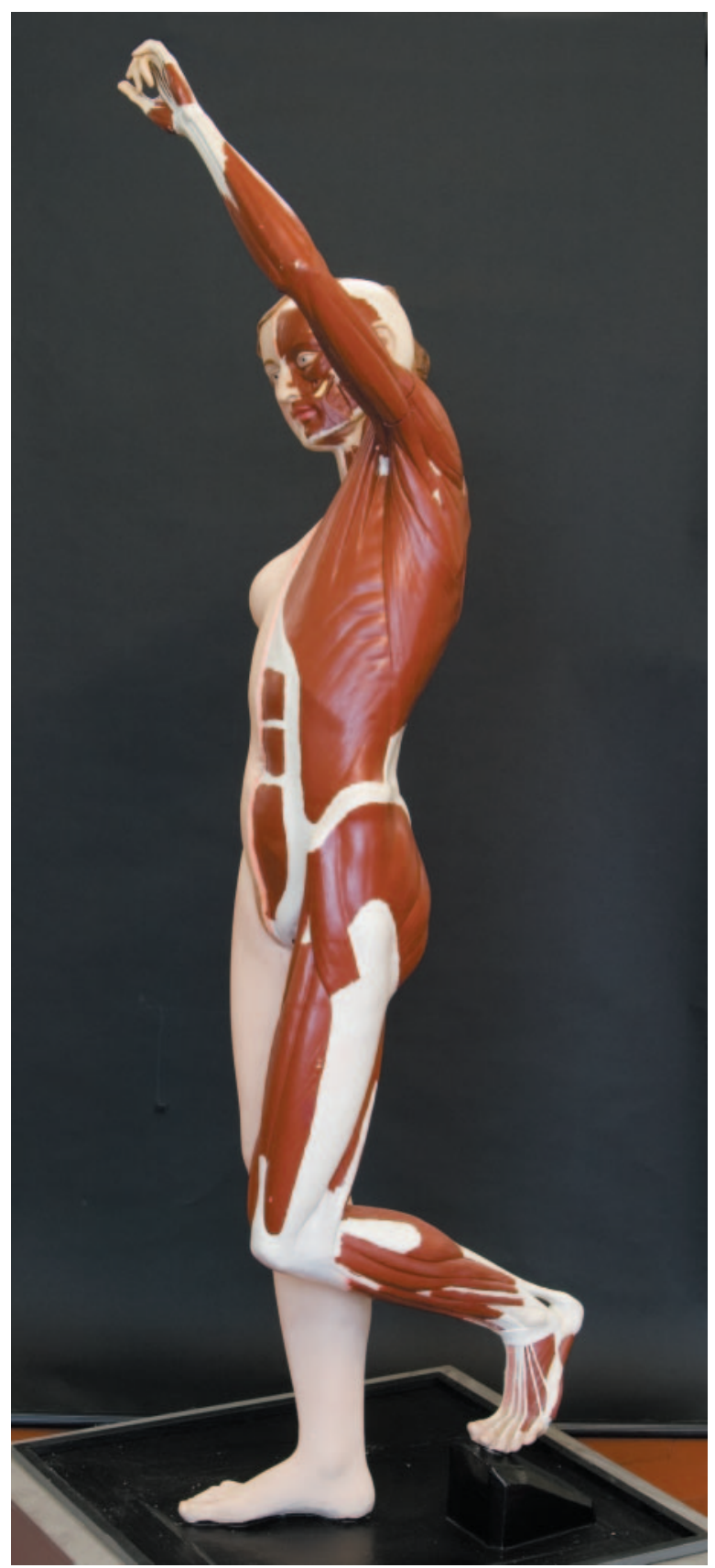

Figure 4: Full-size female statue in plaster, half-anatomical, signed "P. Zeiller". Paul Zeiller senior displayed such a model at the Munich industrial exhibition of 1854 and in his anthropological museum; this one has been repainted. Anatomische Anstalt München; photo by Prof. Dr Rainer Breul. 


\section{Models, Dissection and the Revolution of 1848}

Paul Zeiller's university job gave him access to material and a certain status; minor problems and under-employment notwithstanding,${ }^{90}$ the situation remained stable. But in 1857, having completed his ten years, he demanded a chair of plastic anatomy or threatened to leave. The faculty still respected his artistic skills. Even the member who dismissed his request as a sign that he not only suffered from "arrogance" but was "in danger of becoming mentally ill, or already has done", argued that the university would get a better deal by buying his waxes piecemeal. But on the advice of the new professor of anatomy and celebrated embryologist Theodor Bischoff, who had been hired in with other non-Bavarians to raise the standard of the university, the faculty rejected the request. ${ }^{91}$ In February 1858 Zeiller resigned and immediately asked for 900 guilders a year for three years, i.e., his previous salary plus expenses, to enable him to build up a collection of waxes that would render dissection superfluous. An irritated Bischoff responded that

the main error of this man, who so much overestimates himself, consists in the delusion that any artificial imitations of the structures of the human body could ever replace the study of and engagement with nature; instead he should endeavour to use his abilities to represent such objects as are difficult to study in nature because of their delicacy or smallness or because of too large demands on time and skill.... His enterprise is foolish and has absolutely no value for medical studies, as earlier periods and enterprises and millions expended on them long ago proved ...

In the unlikely event that the project succeeded, the faculty would have to come out against it, Bischoff wrote, but he was still willing to employ Zeiller ad hoc and to support a request for personal assistance from other funds. Weissbrod, now eighty, could object only to Bischoff's description of "the outstandingly eminent artist" as a "not untalented man". 92 Zeiller asked for money again in 1862, and the following year threatened to publish a denunciation unless he was granted a pension (with back-pay), space to display his collection and either free use of the anatomical institute or the right to every tenth, fifteenth and twentieth corpse it received. Almost needless to say, the faculty resisted this blackmail. ${ }^{93}$

Private anatomical and ethnographic museums traditionally appeared in histories, not of science or medicine, but of shows. ${ }^{94}$ Historians are now reconstructing the relations and

321-22, p. 322. She also authored Beiträge zur Entwicklungsgeschichte des Menschen, des

Säugethiers und des Vogels, Munich, 1877.

${ }_{90}$ E.g., UAM, N-I-28, rector to faculty, 29 Mar. 1852.

${ }^{91}$ Ibid., N-I-33, faculty circular, 8 June 1857: “vom

Hochmutsdünkel befallen ... in Gefahr steht geisteskrank zu werden, od. bereits geworden ist"; N-I-34, rector to faculty, 21 Feb. 1858.

${ }^{92}$ Ibid., N-I-34, Bischoff's 'Votum informativum', 22 Feb. 1858: "daß der Hauptirrthum dieses sich so sehr überschätzenden Mannes in dem Wahne besteht, daß irgendwelche künstlichen Nachahmungen der Gebilde des menschlichen Körpers das Studium u die

Beschäftigung mit der Natur jemals ersetzen könnten, anstatt daß er bemüht seyn sollte, seine Fähigkeiten auf Vorstellung solcher Gegenstände zu verwenden, deren Studium in der Natur wegen ihrer Zartheit oder
Kleinheit oder wegen zu großer Anforderung an Zeit u Geschicklichkeit, Schwierigkeiten darbietet. ... Sein Unternehmen ist thöricht $u$ hat für das medicinische Studium gar keinen Werth, wie vorausgegangene Zeiten u Unternehmungen u darauf verwendete Millionen längst bewiesen haben ... nicht talentlosen Mannes". Bischoff must have had the Florentine collections in mind. There follow responses of the faculty (Weissbrod: "den vorzüglich eminenten Künstler") and minutes of the meeting of 20 Mar. 1858.

${ }^{93}$ Ibid., N-I-38, senate to faculty, 24 Feb. 1862; N-I40, minutes of meeting, 23 Dec. 1863.

${ }^{94}$ König and Ortenau, op. cit., note 10 above; Richard D Altick, The shows of London, Cambridge, MA, Harvard University Press, Belknap Press, 1978, pp. 338-42; Stephan Oettermann, 'Alles-Schau.

Wachsfigurenkabinette und Panoptiken', in Lisa Kosok and Mathile Jamin (eds), Viel Vergnügen. Öffentliche 


\section{Nick Hopwood}

traffic between commercial displays and state institutes, while acknowledging the work that showmen and professors put into keeping them apart. In university museums and fairground exhibits even the same models could acquire very different meanings. ${ }^{95}$ For Munich, such research has begun for the decades around 1900, but the picture of the 1860s is still dominated by the foundation of the initially unsuccessful state ethnographic museum. ${ }^{96}$ More generally, our understanding remains asymmetrical: we readily assign university anatomists to disciplinary orientations, but are only beginning to differentiate between private museums. At first sight, the mix of sensation and education appears the same. By approaching Zeiller's museum through his distinctive agenda, and by comparing the range of his exhibits, we can begin to recover how this one stands out. ${ }^{97}$ Leaving the specifics of his anthropology and its relations to Darwinism on one side, the focus here is on his claims for models versus dissection.

Following a general political thaw, the museum opened in 1861 and again every summer through the 1860 s and 1870 s. Zeiller thus contributed to a mid-century expansion of such institutions-including Joseph Kahn's in London, Pierre Spitzner's in Paris and A Präuscher's in Berlin and other German towns-some of which may already have displayed his models. ${ }^{98}$ Zeiller justified the venture with conventional appeals to know thyself and praise the creator in his greatest work. Anatomy, which had remained "until now almost exclusively the property of a single corporation", must become more fully the basis of medicine, surgery, art and everyday life. He targeted the general public, especially teachers and parents, and students of art and medicine. ${ }^{99}$

With a programme that was safe by the standards of Kahn, Spitzner and Präuscher, Zeiller set a more serious tone. He showed the apparatus of locomotion, sense organs, the brain, general anatomy (Figure 5) and embryology, plus a "gallery of peoples" modelled after drawings, descriptions and exotic visitors to Munich, London and Paris. There was

Lustbarkeiten im Ruhrgebiet der Jahrhundertwende, Essen, Pomp, 1992, pp. 36-56, 294-302.

${ }^{95}$ Rainer Micklich, 'Louis Castan und seine Verbindungen zu Rudolf Virchow. Historische Aspekte des Berliner Panoptikums', in Susanne Hahn and Dimitrios Ambatelios (eds), "Wachs-Moulagen und Modelle"..., Dresden, Deutsches Hygiene-Museum, 1994, pp. 155-61; Andrew Zimmerman, Anthropology and antihumanism in Imperial Germany, University of Chicago Press, 2001, ch. 1. On models' meanings, see Hopwood, op. cit., note 6 above, pp. 37, 72; on the variety of public anatomies, Buklijas, op. cit., note 2 above, ch. 4.

${ }^{96}$ Anne Dreesbach and Helmut Zedelmaier (eds), "Gleich hinterm Hofbräuhaus waschechte Amazonen". Exotik in München um 1900, Munich, Dölling und Galitz, 2003; Sigrid Gareis, Exotik in München. Museumsethnologische Konzeptionen im historischen Wandel am Beispiel des Staatlichen Museums für Völkerkunde München, Munich, Anacon, 1990; Wolfgang J Smolka, Völkerkunde in München. Voraussetzungen, Möglichkeiten und Entwicklungslinien ihrer Institutionalisierung (ca. 1850-1933), Berlin, Duncker \& Humblot, 1994.

\footnotetext{
${ }^{97}$ On the disciplines, see Lynn K Nyhart, Biology takes form: animal morphology and the German universities, 1800-1900, University of Chicago Press, 1995. For changes in the programme of, and medical attitudes towards, Joseph Kahn, see Maritha Rene Burmeister, 'Popular anatomical museums in nineteenth-century England', $\mathrm{PhD}$ thesis, Rutgers University, 2000.

${ }^{98}$ Plates in Kahn's Atlas of the formation of the human body ..., London, Churchill, 1852, strikingly resemble embryological figures in Zeiller's obstetric atlas, which were drawn in part after his models: Zeiller, Geburtshülflicher Hand-Atlas, op. cit., note 70 above, p. iv. Since Kahn claimed to have provided "faithful copies of the models ... in my Museum, which were executed under the immediate superintendence of the late Professor Erdl” (p. v), he probably bought them from Zeiller. For an undocumented claim that Spitzner did too, see Hélène Pinet, 'Cires anatomiques', in Le corps en morceaux, Paris, Réunion des musées nationaux, 1990, pp. 51-6, on p. 53; and Lemire, op. cit., note 1 above, pp. 341-2, 427.

${ }^{99}$ Zeiller, op. cit., note 32 above, pp. 3-4: "bisher fast ausschließlich das Eigenthum einer einzelnen Corporation".
} 


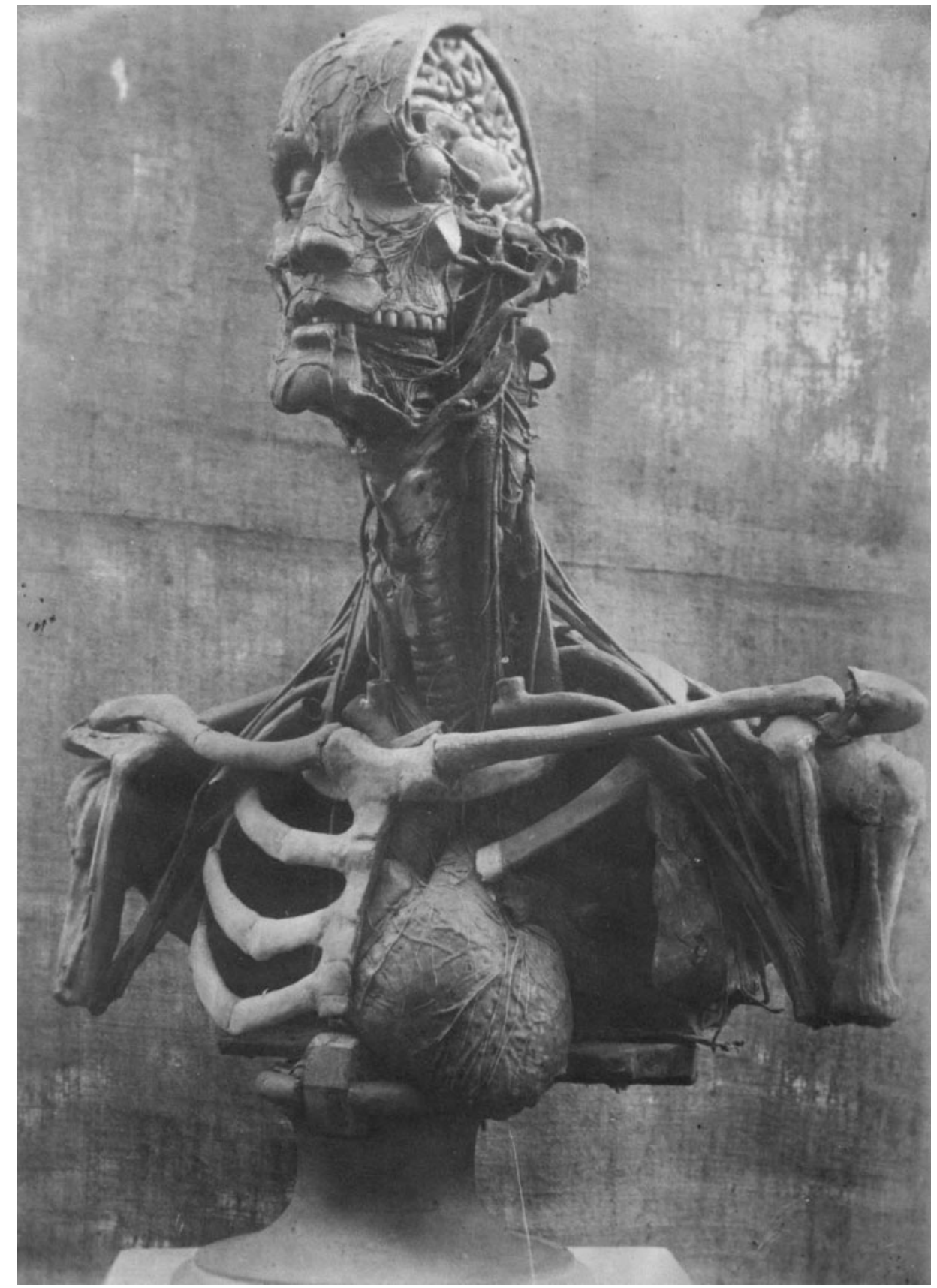

Figure 5: Photograph of an "[e]nlarged anatomical head modelled by Paul Zeiller I in the year 1860 1864 in Munich", possibly the most dissected in a series of three enlarged male busts displayed in his anthropological museum: Führer durch die Säle des anthropologischen Museums, Munich, 1862, pp. 40-2. From 'Ehren-Buch der Familie Paul Zeiller II', c.1918, courtesy of Elsbeth Schramm. 


\section{Nick Hopwood}

the obligatory Venus and a host of other female and male figures in various states of undress and dissection, but no obstetrical operations, torture chamber, teratology or isolated genitalia, let alone any venereal disease. ${ }^{100}$ Also unusually, Zeiller focused on models alone. The science had been offered, he claimed, exclusively through dissection for medics and in books that, even with flat pictures, "the initiated" alone could understand. Only modelling, which he presented himself as introducing to Germany, could build "a bridge across which the thinking layman can comfortably reach the deepest mysteries of the creator". ${ }^{101}$ Yet though from the late eighteenth century laypeople were increasingly excluded from dissections, they could already see wet and dry, natural and artificial preparations in, for example, Präuscher's museum and the Munich anatomical institute. $^{102}$

The museum guides avoided confrontation, but Paul and especially Franziska Zeiller also campaigned more explicitly against official opposition. Paul had mentioned Goethe in print as early as $1849,{ }^{103}$ and he became a particularly attractive resource in spring 1864 , when the Zeillers' museum toured to Frankfurt am Main. Here they were snubbed by the conservative Senckenberg Society for Research into Nature but welcomed by the German Independent Academy, a radical post- 1848 attempt to create a national institute in Goethe's natal home. ${ }^{104}$ Franziska Zeiller spoke and wrote on her husband's behalf while he was indisposed with "a nervous complaint"; his persecution justified a wife's leaving "the quiet sphere of domesticity" and arming herself "with manly courage". In a long article in a liberal-democratic newspaper quotes from Wilhelm Meister helped explain the "artificial oppression" of plastic anatomy in Germany. ${ }^{105}$

Art and science might have worked together hand in hand, Franziska Zeiller argued, but for the "knife anatomists", "natural opponents" who unfortunately had the power to decide the value of models. So no collection bore the name of the "oppressed artist" who had produced it, only that of the scholar in charge. "Zeiller dared for the first time to attempt to clear an honourable path for himself and for his colleagues." ${ }^{106}$ As a "sculptor and anatomist", he boasted of making his own natural preparations and claimed property

\footnotetext{
${ }^{100}$ Catalogue of Dr. Kahn's Anatomical Museum, now exhibiting at 315, Oxford Street ..., London, Golbourn, 1851; Wegweiser durch A. Präuscher's großes anatomisches Museum ..., Leipzig, 1855; Catalogue du Grand Musée d'Anatomie du Dr P. Spitzner ..., Paris [c.1896].

${ }^{101}$ Zeiller, op. cit., note 32 above, pp. 4-6: “dem Eingeweihten ... eine Brücke ... über welche der denkende Laie bequem zu den tiefsten Schöpfergeheimnissen gelangen kann".

${ }^{102}$ Carl Baedeker, Süd-Deutschland und Österreich. Handbuch für Reisende, 16th ed., Koblenz and Leipzig, 1873, pp. 111, 143. For changes in the audience for dissections, see Stukenbrock, op. cit., note 2 above, p. 153

${ }^{103}$ Zeiller, op. cit., note 25 above. Anatomists were more concerned with Goethe's comparative anatomy: Wilhelm Lubosch, 'Was verdankt die vergleichendanatomische Wissenschaft den Arbeiten Goethes?', Jahrbuch der Goethe-Gesellschaft, 1919, 6: 157-91.
}

Schwalbe, op. cit., note 4 above, found no reference in the literature on moulages.

${ }^{104}$ X, op. cit., note 89 above. Ayako Sakurai,

'Science, identity and urban reinvention in a mercantile city-state: the associational culture of nineteenthcentury Frankfurt am Main', PhD thesis, University of Cambridge, 2006, ch. 4, shows that the Freies Deutsches Hochstift appealed especially to immigrant intellectuals, in whose circles the Zeillers would most easily have moved. Both became "masters" and honorary members: FDH, Mitgliedsakten.

${ }^{105}$ F Zeiller, op. cit., note 19 above, pp. 1, 8: “in künstlicher Unterdrückung ... ein Nervenleiden ... in dem stillen Kreise der Häuslichkeit ... mit männlichem Muthe".

${ }^{106}$ Ibid., pp. 1-2: "ihren natürlichen Gegnern ... Messeranatomen ... des unterdrückten Künstlers ... Zeiller wagte zum ersten Male den Versuch, für sich selbst und für seine Fachgenossen eine ehrenhafte Bahn zu brechen." 


\section{Models, Dissection and the Revolution of 1848}

rights in his wife's alleged discoveries in embryology. ${ }^{107}$ He reckoned to follow Goethe not just in plastic anatomy, but also in a morphological approach that required the artistic training Erdl had enjoyed but most anatomists lacked. ${ }^{108}$

Recognizing dissection as the fount of anatomical knowledge, the Zeillers insisted on its didactic shortcomings. One picture gave way under the knife to another until any possibility of an overview was lost. The healthy living body could not be known just by cutting up decaying, diseased cadavers - even without the perennial problem of supply. Procuring more corpses meant that "innocent poverty is ... punished in vain", when better use should rather be made of the teaching material to hand. Drawings, useful for exchanging knowledge among specialists, were unsuitable for beginners. Only modelling recreated what decay and dismemberment destroyed, and so turned cadavers into memorable, permanent pictures of the living body. ${ }^{109}$

Less radically, the Zeillers argued that, since there was not enough time in the medical curriculum for dissection, students would learn more if they had visited the museum first. Scientific descriptions supplemented the popular guides and the Vienna anatomist Joseph Hyrtl was enlisted as a witness to the value of using visual aids, including models, before hearing lectures and dissecting. ${ }^{110}$ But anatomists still rejected Zeiller's project. In 1871 Bischoff testified that though he "possesses an exceptional level of ability in making wax preparations with elegance and taste", and his models were usable when he followed instructions, "he lacks the necessary anatomical and particularly embryological knowledge" to produce adequate work on his own. "Since, however, he ... takes himself for one of the foremost anatomists, and for this reason is very impervious to instruction and advice, many of his representations are simply not correct", 111

Zeiller did better at the Academy of Arts, now Germany's leading art school, which gave his museum free use of their exhibition building on Königplatz opposite the Glyptothek. When Emil Harless, the associate professor of physiology who had revived their anatomical teaching in the early 1850 s, fell ill in winter 1861-2, they recommended students attend Zeiller's "anatomical course", and the following summer even covered the three-guilder fee for the poor but diligent. ${ }^{112}$ Franziska Zeiller claimed a few years later that after the incumbent professor of anatomy died, teachers and pupils unanimously elected Zeiller to succeed, only for the faculty to change its mind. ${ }^{113}$ Yet there was no anatomical chair, the academy just paid a lecturer, and the ministerial file tells

\footnotetext{
${ }^{107}$ Zeiller, op. cit., note 25 above, t.p. ("Bildhauer und Anatom") and p. 6; FDH, Zeiller to Hochstift, 24 May 1864 (discoveries).

${ }^{108}$ Zeiller, 'Vortrag', op. cit., note 30 above.

${ }^{109}$ F Zeiller, op. cit., note 19 above, pp. 2-3, 5: “Die unverschuldete Armuth wird ... vergebens bestraft." She saw English legislation as exemplary.

${ }^{110}$ Ibid., pp. 1-4. On the scientific guides, see Zeiller, op. cit., note 32 above, t.p. and p. 19; and on Hyrtl, Buklijas, op. cit., note 2 above, ch. 3.

${ }^{111}$ BAWZ, Bischoff to Generalkonservatorium, 27 Jan. 1871: "Zeiller besitzt die Fähigkeit in ausgezeichnetem Grade Wachspräparate mit
}

Eleganz u Geschmack anzufertigen ... so manglen [sic] ihm die nöthigen anatomischen $u$ namentlich embryologischen Kenntnisse ... . Da er sich ... für einen der ersten Anatomen hält, aus diesem Grunde aber sehr unzugänglich für Belehrung u Rath ist, so sind viele seiner Darstellung [sic] durchaus nicht correct".

${ }^{112}$ BHSAA, academy to Kultusministerium, 5 May 1862; Paul Zeiler [sic], 'Anatomischer Cursus', Bayerische Zeitung, 1864, 1063, consulted as a clipping, Stadtarchiv München (hereafter StAM), ZA 1518.

${ }^{113}$ F Zeiller, op. cit., note 19 above, p. 5. 


\section{Nick Hopwood}

a different story about how the deceased Harless was replaced. Perennially concerned that the anatomical teaching should not be too theoretical, the academy planned to take half of the lecture time for students to draw muscles and bones from models. But though the art professors found Zeiller's preparations "excellent", "his demands in relation to their purchase exceed by more than tenfold the sum which the academy could spend; he is also less trained for the lecturing itself than for the modelling work, and our experience with him is not such that we could expect that he would willingly organize his teaching according to the wishes and purposes of the academy. Using his preparations we would be dependent on him, which could have considerable disadvantages." So they decided instead to employ a new Privatdozent at the university, Julius Kollmann, to lecture on anatomy and inexpensively to prepare some models in plaster and painted papier mâché, from which one of their own assistant teachers would run classes in anatomical drawing. ${ }^{114}$

Though lacking state recognition, the Zeillers did good business. ${ }^{115}$ They continued to set up the museum every summer, from 1871 in the Crystal Palace built for the 1854 industrial exhibition. Fanny, their sons and employees did much of the work, while for his health Paul spent ever more time south of the capital "on his country estate" in the village of Grünwald. ${ }^{116}$ They did not gain a permanent centre of instruction, but in 1879 bought the medieval Grünwald Castle at auction for 10,600 marks. ${ }^{117}$ Franziska died in 1881 and Paul in 1893 of the complications of a fall in about $1887 .{ }^{118}$ Their sons Robert (1846-1918) and Paul junior (1851-1923) trained as sculptors. Robert briefly co-ran a panopticon with the scion of another modelling family, Emil Eduard Hammer, in Munich's Café Luitpold. ${ }^{119}$ Paul studied at the Academy of Arts and was then apprenticed to a mechanic; he supplied clockwork waxworks to panopticons all over Europe. He also took over the castle. Visitors saw the anthropological museum and took refreshments; neo-romantics in armour became the fearlessly inebriated knights immortalized by the comedian Karl Valentin. ${ }^{120}$

\footnotetext{
${ }^{114}$ BHSAA, academy to Kultusministerium, 2 July 1862: "Die Präparate ... sind vortrefflich, aber seine Forderungen in Bezug auf den Ankauf überschreiten die Summe, welche die Akademie aufzuwenden vermöchte, um mehr als das zehnfache; er ist dabei für den Vortrag selbst weniger ausgebildet als für die plastischen Arbeiten und unsre Erfahrungen mit ihm sind nicht der Art, daß wir erwarten könnten, er werde seinen Unterricht nach den Wünschen und Zwecken der Akademie gern und willig einrichten. Seine Präparate benutzend wären wir in einer Abhängigkeit von ihm, welche ihre starken Schattenseiten haben könnte." Kollmann lectured until 1878: H K Corning, 'Julius Kollmann. † 24. Juni 1918', Anat. Anz., 1919, 52: 65-80, p. 67. Zeiller was nevertheless known in some circles as "professor": König and Ortenau, op. cit., note 10 above, p. 95.

${ }^{115}$ In Frankfurt the show received 9,000 visitors in under three months: X, op. cit., note 89 above, p. 318; and the Munich reopening was successful: FDH, F Zeiller to [Theobald Schideck], 13 July 1864.
}

${ }^{116}$ Fanny Zeiller and Otto Zeiller, Die Todtenmaske Napoleons I ..., Munich, 1872, pp. 3-4: "auf seinem ländlichen Anwesen".

${ }^{117}$ Joachim Wild, Prähistorische Staatssammlung. Museum für Vor- und Frühgeschichte. Führer durch die Geschichte der Burg Grünwald, 2nd ed., Munich, Prähistorische Staatssammlung, 1993, p. 48.

${ }^{118}$ Staatsarchiv München (hereafter StsAM), Amtsgericht München, 2093, 1881 (Franziska); N, op. cit., note 26 above (Paul).

${ }^{119}$ Münchener Fremdenblatt, 14 Feb. 1893, StAM, ZA 878.

120 'Ehren-Buch', op. cit., note 29 above; König and Ortenau, op. cit., note 10 above; Max Ernst, 'Großer Förderer der Gemeindeinteressen. Paul Zeiller (II)', in idem, op. cit., note 10 above, pp. 33-4; Hans Waldhauser, Grünwald Chronik, vol. 2: Vom Bauerndorf bis heut', Grünwald, Vereinigung der Freunde Grünwalds, 1991, pp. 435-7, 456, 462-3; Wild, op. cit., note 117 above, p. 48. 


\section{Models, Dissection and the Revolution of 1848}

Financial success apart, it might seem clear that Zeiller lost his battle over models versus dissection. In 1907 instruction at the cadaver was entrenched in a $600 \mathrm{~m}^{2}$ dissection hall in Munich's splendid new art-nouveau anatomy building. But university anatomists here as elsewhere were increasingly concerned to offer visual aids, including models, from which students could revise. ${ }^{121}$ Provided the professors could set the terms, they were keen to collaborate with modellers on normal adult anatomy. ${ }^{122}$ Today, as other medical schools abandon dissection altogether, Zeiller's arguments resonate anew. Nor is it obvious that his family history represents any general split between popular museums and state institutions. Paul junior and Robert Zeiller did not re-establish relations with the university, but Hammer, who became one of Germany's most prominent panopticon owners-he later put on a "people's medical museum" and hygiene exhibitions-was awarded the (honorary) title of Universitätsplastiker and Munich's anatomical institute was and is full of his models. ${ }^{123}$ Eugen Schneider is now forgotten even there, but a large Zeiller statue is prominently displayed (Figure 4).

\section{Conclusion}

Goethe's plea for plastic anatomy was neither the last nineteenth-century attempt to promote models as alternatives to teaching by cadaver dissection, nor the most sustained. Paul and Franziska Zeiller were still working nearly half a century later to realize a vision of artificial anatomy, not just for laypeople and artists, but also to replace medical instruction at the corpse. He may have seriously worried the Munich anatomists for only a few weeks, but the challenge lasted, and continued to provoke responses, for two to three decades. It should expand our political geographies of modelling, of dissection and of the institutions of medical science.

Paul Zeiller's remarkable trajectory links the various milieux of modelling in the nineteenth century, from royal collections to popular shows, from in-house work for institutes and clinics through general businesses supplying universities, schools, museums and individuals to Adolf Ziegler's network of authors and purchasers among the leading professors. Many of these artists' careers involved struggles for recognition by medical authority and the state. In a ferment of activity around mid-century, Ziegler and Zeiller respectively represent extreme cooperation and conflict with academic medical patrons and clients: if Ziegler shows how models could achieve high status, Zeiller defines the limits of defiance. Comparison throws their contrasting strategies into relief. Ziegler

\footnotetext{
${ }^{121} \mathrm{~J}$ Rückert, Die neue anatomische Anstalt in München, Wiesbaden, Bergmann, 1910, pp. 38-9, 41 and pl. 3.

${ }^{122}$ In Leipzig Wilhelm His had Franz Joseph Steger make widely used plaster casts of cadavers: Cornelia Becker, et al., Das Institut für Anatomie in Leipzig. Eine Geschichte in Bildern, Beucha, Sax, 2005, pp. 42-4. From 1888 Wilhelm Waldeyer led Berlin anatomists in directing Karl Schütz to produce a muscle torso: Geheimes Staatsarchiv Preußischer Kulturbesitz, I. HA Rep. 76
}

\author{
Kultusministerium Va Sekt. 2 Tit. 10 Nr. 10 \\ Bd. IX-XII. \\ ${ }^{123}$ BHSA, MK 11328, 1915 (title); StsAM, \\ Amtsgericht München, 4106, 1938-9 (purchase from \\ estate and previously). On Hammer, see StAM, ZA \\ 878; StsAM, Polizeidirektion München, 1051; \\ Röhrich, op. cit., note 10 above; and, most recently, \\ Martin Rühlemann, 'Das Internationale Handels- \\ Panoptikum: ein Massenmedium der Exotik', in \\ Dreesbach and Zedelmaier (eds), op. cit., note 96 \\ above, pp. 34-52.
}




\section{Nick Hopwood}

differed less in his medical degree than in his management of scientists. He submitted to academic control, while Zeiller, claiming to be an anatomist in his own right, competed to teach the science to doctors and artists. Ziegler created an opportunity from specialization; Zeiller exploited the peculiar conditions of Vormärz Munich to resurrect a vision of encyclopaedic anatomical instruction for all. Franziska Zeiller's prominence in the partnership is also unconventional. This was an exceptional couple, but more conciliatory modellers also had to negotiate the issues that the Zeillers' controversies make so richly explicit.

Paul Zeiller appears to have identified with the revolution as underwriting artistic autonomy against arbitrary authority, and with liberal demands for equal rights and access to knowledge. But he remained loyal to a selective image of the Restoration patrons to whom he owed his position, the monarchy and some conservative professors, harked back with Goethe to Florence, and ended his life in a castle. In 1848, by aligning his campaign for recognition as an artist with popular unrest at inequality after death, he made the politics of models intersect with those of anatomical corpse supply. Systematic research on dissection of the destitute is only beginning for the German lands in the nineteenth century; the reports from Munich are rare evidence of an attempt to mobilize public opinion for reform. More generally significant is the way these larger politics were bound up with technical debates over teaching methods and fought out within anatomy institutes as well as around them. Artists, preparators and technicians occupied strategic positions that deserve further study: participating in the everyday work of the science, they were well placed to mediate - or stir up trouble-between professors and plebs. The status of dissection, models and other visual aids continued to be negotiated in their struggles for recognition.

Many scientific enterprises were founded in the German lands in response to political frustration in the reactionary 1850 s and then to the new era after 1858, but the emphasis has been on civic associations, the museums they created and, especially, print. ${ }^{124}$ Zeiller's venture turns out to belong in the same frame. Exploring further such prominent sites of anatomy and anthropology during the first middle-class engagement with Darwinism should refine our understanding of similarities and differences among commercial museums and between them and state institutions. It is already clear that though accounts of Zeiller's life have presented his university post as a simple springboard for a family of artists, showmen and castle owners, the museum in fact continued a contest for authority begun in 1848. Indeed, it was apparently not until the 1860s, for the German Independent Academy, that Franziska Zeiller publicly articulated the full-blooded critique of knife anatomy. Recovering their campaign reveals hidden politics of modelling, dissection and medical science.

${ }^{124}$ Daum, op. cit., note 46 above. 